\title{
3D transient heat transfer numerical analysis of multiple energy piles
}

\author{
Yuanlong Cui, Jie Zhu* \\ Department of Architecture and Built Environment \\ University of Nottingham, University Park, Nottingham NG7 2RD, United Kingdom
}

\begin{abstract}
This paper presents a three-dimensional (3D) transient heat transfer numerical model for multiple energy piles based on the finite volume method (FVM). The initial and boundary conditions are established and the effects of "thermal short-circulating" between two pipes of a U-tube in energy pile are investigated. Thermal partial differential equations are discretized at the spatial nodal points and solved by linear approximation method. Temperature variations of working fluid, energy pile and its surrounding soil from simulation program are compared with experimental data to validate the developed model. In addition, the influences of fluid flow rate and U-tube shank spacing are analysed. It is established that the shank spacing should be set in a range of $0.06 \mathrm{~m}$ to $0.10 \mathrm{~m}$ to reduce heat transfer between the two pipes and meet the structural requirement. Meanwhile, the flow rate should be controlled in a range of $0.5 \mathrm{~m}^{3} / \mathrm{h}$ to $0.7 \mathrm{~m}^{3} / \mathrm{h}$ to avoid the low outlet fluid temperature and decrease the influence of "thermal short-circuiting".
\end{abstract}

Keywords: Energy pile, 3D numerical model, FVM, Thermal short-circulating, Shank spacing

\section{Introduction}

Shallow geothermal energy can be utilized to provide space air conditioning for building application. The subsurface ground temperature is higher than the ambient temperature in winter and lower in summer, thereby the ground can be used to provide heat in winter (as heat source) and cool in summer (as heat sink) [1]. Ground source heat pump (GSHP) is one of the systems that take advantage of this shallow energy through ground heat exchangers, such as borehole heat exchanger (BHE). A typical BHE consists of one or two plastic U-tubes, mainly polyethylene or polypropylene, inserted into a borehole and fixed with grout. A working fluid is circulated within U-tube to exchange heat with the ground. Due to the high initial installation cost, ground heat exchanger is integrated into building foundation system, known as "Energy Pile" (EP) [2-7]. The primary merit of the EP is its dual functions as building structural component and heat exchanger. Moreover, concrete is regarded as an idea heat transfer intermediate owing to its good thermal conductivity and thermal storage capacity [8,9]. Studies have shown that GSHP with the

${ }^{*}$ Corresponding author. Tel: +44-115-8466141 Fax: +44-115-951315

E-mail address: jie.zhu@ nottingham.ac.uk 
EP system can save up to $75 \%$ of energy for building space heating and cooling compared to the conventional air conditioning system [1-3].

A typical EP structure is shown in Fig. 1. Its main components are the reinforced concrete borehole and U-tube. Many research works have been carried out to investigate BHE heat transfer using analytical, numerical and combined methodologies. Eskison [10] presented a primary model to determine the mean borehole wall temperature by combining numerical finite difference method (FDM) with finite line source model. It is based on the use of non-dimensional temperature response factor, named " $\mathrm{g}$ function". The time for a heat impulse of working fluid to reach steady state at the borehole wall is determined and the valid time is proposed. Hellstrom et al. [11, 12] proposed a duct storage model (DST) to compute the system efficiency, and utilized a twodimensional (2D) finite difference scheme to determine soil temperature variation. Yavuzturk et al. [13, 14] set up a 2D transient numerical model to simulate short timescale responses based on the finite volume method (FVM), and modified Eskilson's model (g-functions) for the short time step (as short as a few minutes) simulation. The authors later refined their initial model by taking the fluid and grout thermal capacities into account [15]. Maestre et al. [16] developed a simplified model to simulate heat transfer behaviour within single U-tube BHE based on the electrical analogy method. Thermal response factors (g-functions) are utilized to evaluate injection-extraction heat flow to nearby soil, and thermal capacities of the fluid and grout are taken into account for simulating the short-term operation under different boundary conditions. Huber et al. [17] developed the EWS model for BHE with double U-tubes and simulated the short time response by solving one-dimensional (1D) heat transfer equation in the radial direction with the Crank-Nicholson algorithm. Oppelt et al. [18] presented a MISOS model by dividing grout and pipe into different temperature zones. The MISOS model is used to simulate GSHP annual performance with a time step of about one hour and calculate the grout element temperature based on the element energy balance. Carli et al. [19] produced a capacity resistance model (CaRM) to analyse the working fluid temperature distributions for various BHE configurations where a local steady-state heat transfer is considered with the amended boundary conditions. Zarrella et al. [20] made an improvement on the model of double U-tubes by taking borehole thermal capacitance node into account based on electrical analogy. Their analysed results illustrate that thermal capacitance of the working fluid plays a significant role in the short time step simulation. Bozis et al. [21] developed a methodology to assess the effects of energy pile design alternatives, which is based on the implementation of line source theory to the EP specific geometry. They found that the temperature variation at the pile axis does not depend on the number of U-tubes and flow states under the constant heat rejection condition. Hu et al. [22] presented a composite cylindrical model on the basis of the combination of line source and cylindrical models, which can be used to estimate the transient heat transfer and temperature response over a short time period. They found that the distance between the pipe and BHE wall is a significant factor influencing heat transfer within the BHE. 


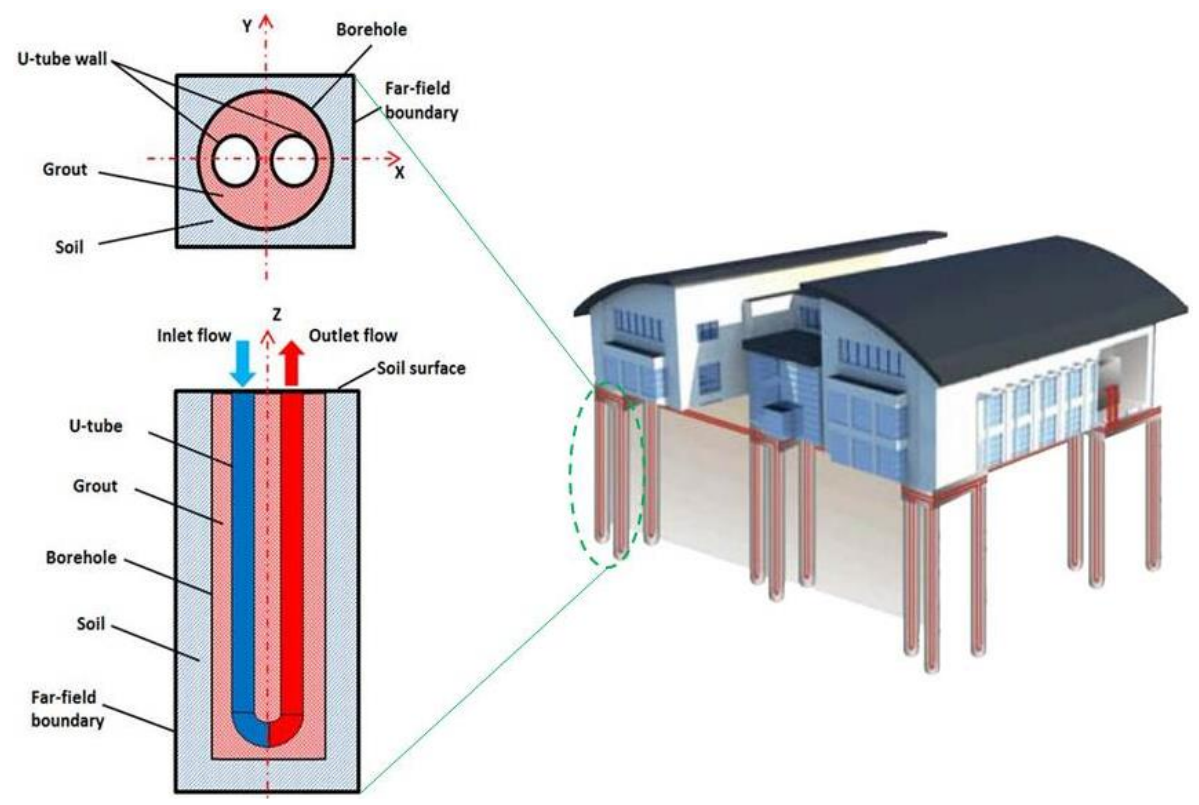

Fig.1. Scheme diagram of EP elements

Bauer et al. [23] produced 2D thermal resistance and capacity model (TRCM) for the coaxial, single and double U-tube boreholes to determine temperature distribution within the whole domain, the thermal resistances are related to the ratio of the pipe's surface to the grout's surface, one capacity node per tube is proposed by taking the fluid and grouting materials into account, however, the shank spacing influence has not yet been considered in this model. Huber et al. [24] improved the TRCM for the BHE short-time thermal behaviour simulation based on the electrical analogy. Pasquier et al. [25] presented an extended approach of approximation borehole components by supplementing some nodes to the grout area, which accounts for the fluid and pipe capacities as well as shack spacing. Most 2D BHE transient heat transfer models are based on the FEM and FDM. 2D models provide the detailed depiction of the BHE by thermal resistances, thermal properties of pipes and grout are considered, nevertheless, thermal interference or "thermal short-circulating" [26, 27] between two pipes of U-tube is neglected in 2D models. Al-Khoury et al. [28-30] proposed 3D numerical model depicting thermal interactions among the BHE elements including inletpipe, outlet-pipe and grout. This model addresses the formulation equilibrium, the effect of thermal resistance and the FEM discretization. Nabi et al. [31, 32] also developed a computational model based on 3D FVM, which is used to simulate heat transfer and fluid flow in the shallow BHEs. Rees et al. and He $[33,34]$ set up a 3D BHE numerical model known as general elliptical multi-block solver to simulate transient heat transfers. By applying step changes in inlet parameters, simulation results display the delayed response associated with fluid flow along U-tube. The delay is significant when a system runs at peak load or the intermittence-controlled mode. Gashti et al. [35] proposed a 3D numerical heat transfer model based on finite element theory to analyse the performance of steel pile foundations by the Comsol Multiphysics package. Their study results show that the stabilised pile wall temperature is around $25-33 \%$ difference with the inlet fluid temperature, and there is a big fluctuation in pile shaft temperature near the tube curve at the EP end. Bnilam et al. [36] proposed a semi-analytical model for transient heat 
flow with friction heat gain in a single U-tube BHE based on the spectral analysis and eigenfunction expansion method. In this study, the friction effect is regarded as a nonhomogeneous term in the partial differential equations. The developed spectral model can be utilized for other applications as well, such as narrow pipe flow, high velocity and viscosity flows. Lee [37] proposed a modified 3D numerical heat transfer model to analyse the impacts of grout thermal capacitance and fluid circulation period inside the U-tube. It is found that the fluid temperature changes sharply at the interface between the entering and existing fluids within the BHE. Moreover, the deviation in the simulated outlet fluid temperature of BHE between long-term and shortterm methods could be up to $3^{\circ} \mathrm{C}$ when a periodic intermittent load is considered. Dehkordi et al. [38] developed a tight BHE model for low shank spacing between the inlet and outlet pipes. The proposed model is used to estimate soil thermal conductivity and effective borehole thermal resistance. Their results show that the temperatures of the loop fluid and borehole wall are sensitive to the shank spacing and borehole diameter. It is found that the proximity of the pipes to borehole wall is more significant than the shank spacing in decreasing the total borehole resistance or temperature difference between loop fluid and borehole wall. Moreover, it is verified that a tight BHE could have rather low effective borehole thermal resistance and correspondingly achieve a high thermal efficiency. Yu et al. [39] developed a simplified heat transfer model to investigate thermal performance of large-scale BHE based on the geometric symmetry of borehole layout. Three case studies with various soil thermal conductivities $(1.2,1.6$ and $2.0 \mathrm{~W} / \mathrm{m} \cdot \mathrm{K})$ are presented. In terms of each case study, both the soil thermal balance and imbalance are taken into account along with various BHE layouts. In addition, the relative error is defined as the ratio of the temperature difference (between the representative borehole and the original borehole) to the temperature excess of the representative borehole, and all errors are less than $7.71 \%$ for three cases with balanced seasonal load, and less than $0.56 \%$ for those with imbalanced annual load.

3D models discretize the borehole components and working fluid along the pipe, and provide more accurate representation of heat transfer process. However, there are few mathematical models focusing on heat transfer in the shallow energy piles, which reflect the influence of "thermal short-circuiting". Currently, there is a research gap to predict the multiple energy piles performance with consideration of "thermal short-circuiting" effect for the long-term operation period. The aim of this study is to develop a 3D transient heat transfer model of multiple energy piles to fill the above research gap, which is used for predicting the EP heat transfer rates and assessing thermal interactions under various flow rates and shank spacing. Equivalent geometry approximation is adopted to transform the EP U-tube from circular cross-section into rectangular one. Energy balance models in solid and fluid regions are developed separately; EP boundary conditions are proposed for various conjugated surfaces. In addition, the working fluid temperature variation along the pipe is analysed and the "thermal short-circuiting" heat loss rate is clarified. More than half a year experiment data have been used to verify the developed model, so the model could be used to evaluate long-term thermal performance of multiple energy piles. 


\section{Numerical models}

Heat transfer phenomena of EPs are complicated owing to three-dimension and unsteady state. Many factors such as the boundary condition, working fluid flow rate, soil property, etc. influence heat transfer characteristics. In order to develop a 3D transient heat transfer model, the simplified assumptions in this study are made as follows:

1) The ground is regarded as a homogeneous medium with the mean thermal physical properties.

2) The initial soil temperature is assumed as a function of depth.

3) Heat transfer in the solid region is regarded as pure heat conduction and the effect of groundwater flow is negligible.

4) A profile of velocity in U-tube pipe is uniform.

Ground surface temperature would be directly affected by the solar radiation when the ground surface is fully exposed to outdoor environment. However, when the ground surface is covered by a building, all the radiations from nearby buildings and sky would be sheltered resulting in a low temperature fluctuation near the ground surface. Therefore, in this study, the ambient temperature is just used to represent the ground surface temperature [40, 41]. In terms of the working fluid flow region, energy formulations of the inlet and outlet pipes need to be setup separately because of the flow directions, and governing equations in the solid and fluid regions are derived based on the FVM.

2.1 Single EP model

\subsubsection{Equivalent geometry approximation}

Heat transfer model is developed based on "equivalent pipe method", the geometry transformation is illustrated in Fig. 2. U-tube circular cross-section is replaced by a rectangular one where the equivalent pipe sides are determined to ensure the equal heat transfer rate after transformation. The equivalent geometric dimensions are given as follow:

1) Equivalent pipe side

Working fluid thermal capacities in the two regions are equal and given as:

$$
\begin{aligned}
& \rho_{\mathrm{f}} \mathrm{c}_{\mathrm{f}} \frac{\pi \mathrm{d}_{\mathrm{pi}}^{2}}{4}=\rho_{\mathrm{f}} \mathrm{c}_{\mathrm{f}} \mathrm{D}_{\mathrm{i}}^{2} \\
& \mathrm{D}_{\mathrm{i}}=\frac{\sqrt{\pi}}{2} \mathrm{~d}_{\mathrm{pi}}
\end{aligned}
$$

The same condition is applied for the pipes:

$$
\begin{aligned}
& \rho_{\mathrm{p}} \mathrm{c}_{\mathrm{p}} \frac{\pi\left(\mathrm{d}_{\mathrm{po}}^{2}-\mathrm{d}_{\mathrm{pi}}^{2}\right)}{4}=\rho_{\mathrm{p}} \mathrm{c}_{\mathrm{p}}\left(\mathrm{D}_{\mathrm{o}}^{2}-\mathrm{D}_{\mathrm{i}}^{2}\right) \\
& \mathrm{D}_{\mathrm{o}}=\sqrt{\frac{\pi}{4}\left(\mathrm{~d}_{\mathrm{po}}^{2}-\mathrm{d}_{\mathrm{pi}}^{2}\right)+\mathrm{D}_{\mathrm{i}}^{2}}
\end{aligned}
$$

To guarantee the equivalent fluid temperature gradient in the two regions, the following equivalence condition should be met. 
$\mu \rho_{\mathrm{f}} \mathrm{c}_{\mathrm{f}} \frac{\pi \mathrm{d}_{\mathrm{pi}}^{2}}{4}=\mu^{\prime} \rho_{\mathrm{f}} \mathrm{c}_{\mathrm{f}} D_{\mathrm{i}}^{2}$

Where $\rho_{\mathrm{f}}, \rho_{\mathrm{p}}$ are the densities of working fluid and pipe material $\left(\mathrm{kg} / \mathrm{m}^{3}\right) ; \mathrm{c}_{\mathrm{f}}, \mathrm{c}_{\mathrm{p}}$ are the thermal capacities of working fluid and pipe material, $(\mathrm{J} / \mathrm{kg} \cdot \mathrm{K}) ; \mathrm{D}_{\mathrm{i}}, \mathrm{D}_{\mathrm{o}}$ are the lengths of inner and outer equivalent sides $(\mathrm{m}) ; \mathrm{d}_{\mathrm{po}}, \mathrm{d}_{\mathrm{pi}}$ are the pipe inner and outer diameters $(\mathrm{m}) ; \mu, \mu^{\prime}$ are the working fluid velocities within the U-tube and equivalent pipe $(\mathrm{m} / \mathrm{s})$.

To ensure the equivalence of heat transfer between the circular and rectangular regions, the thermal resistances between working fluid and grout in the two regions should be equal. The thermal resistance in the circular cross-section region is given by;

$$
\mathrm{R}_{\mathrm{c}}=\frac{1}{\frac{1}{\mathrm{~h} \pi \mathrm{d}_{\mathrm{pi}}}+\frac{1}{2 \pi \mathrm{k}_{\mathrm{p}}} \ln \frac{\mathrm{d}_{\mathrm{p}}}{\mathrm{d}_{\mathrm{pi}}}}
$$

The thermal resistance in the rectangular region is:

$$
\mathrm{R}_{\mathrm{s}}=\frac{2\left(\mathrm{D}_{\mathrm{i}}+\mathrm{D}_{\mathrm{o}}\right)}{\frac{1}{\mathrm{~h}_{\mathrm{s}}}+\frac{\mathrm{D}_{\mathrm{o}}-\mathrm{D}_{\mathrm{i}}}{2 \mathrm{k}_{\mathrm{p}}}}
$$

Heat convection coefficient of the rectangular pipe is expressed as follows:

$$
\mathrm{h}_{\mathrm{s}}=\frac{1}{\frac{2\left(\mathrm{D}_{\mathrm{o}}+\mathrm{D}_{\mathrm{i}}\right)}{\mathrm{h}_{\mathrm{c}} \pi \mathrm{d}_{\mathrm{pi}}}+\frac{\mathrm{D}_{\mathrm{o}}+\mathrm{D}_{\mathrm{i}}}{\pi \mathrm{k}_{\mathrm{p}}} \ln \frac{\mathrm{d}_{\mathrm{po}}}{\mathrm{d}_{\mathrm{pi}}}-\frac{\mathrm{D}_{\mathrm{o}}-\mathrm{D}_{\mathrm{i}}}{2 \mathrm{k}_{\mathrm{p}}}}
$$

Where $R_{c}, R_{s}$ are the thermal resistances of $U$-tube and square pipe $(\mathrm{m} \cdot \mathrm{K} / \mathrm{W}) ; \mathrm{k}_{\mathrm{p}}$ is the pipe thermal conductivity coefficient (W/ $\mathrm{m} \cdot \mathrm{K}) ; \delta$ is the wall thickness of rectangular pipe $(\mathrm{m}) ; \mathrm{h}_{\mathrm{c}}, \mathrm{h}_{\mathrm{s}}$ are the heat convection coefficients of U-tube and square pipes (W/ $\left.\mathrm{m}^{2} \cdot \mathrm{K}\right)$; the subscripts $\mathrm{f}, \mathrm{p}$ denote the fluid and pipe, respectively.

2) Equivalent wall side

To ensure the equivalent thermal capacity for the EP, the square pile area is given in Eq.9.

$\rho_{\mathrm{g}} \mathrm{c}_{\mathrm{g}}\left(\frac{\pi \mathrm{d}_{\mathrm{b}}^{2}}{4}-2 \times \frac{\pi}{4} \mathrm{~d}_{\mathrm{po}}^{2}\right)=\rho_{\mathrm{g}} \mathrm{c}_{\mathrm{g}}\left(\mathrm{l}_{\mathrm{b}}^{2}-2 \times \mathrm{D}_{\mathrm{o}}{ }^{2}\right)$

This equation can also be written as:

$$
\mathrm{l}_{\mathrm{b}}=\sqrt{\frac{\pi \mathrm{d}_{\mathrm{b}}^{2}}{4}-\frac{\pi}{2} \mathrm{~d}_{\mathrm{po}}^{2}+2 \mathrm{D}_{\mathrm{o}}^{2}}
$$

Where $d_{b}$ is the EP diameter $(m) ; \rho_{g}$ is the density of grout $\left(\mathrm{kg} / \mathrm{m}^{3}\right) ; c_{g}$ is the thermal capacity of grout $(\mathrm{J} / \mathrm{kg} \cdot \mathrm{K}) ; \mathrm{l}_{\mathrm{b}}$ is the side length of equivalent pile (m); the subscript $\mathrm{g}$ denotes the backfill material (grout). The center-to-center distance " $\Delta \mathrm{d}$ " between two pipes in the equivalent pile is the same as that in the rectangular pile. 


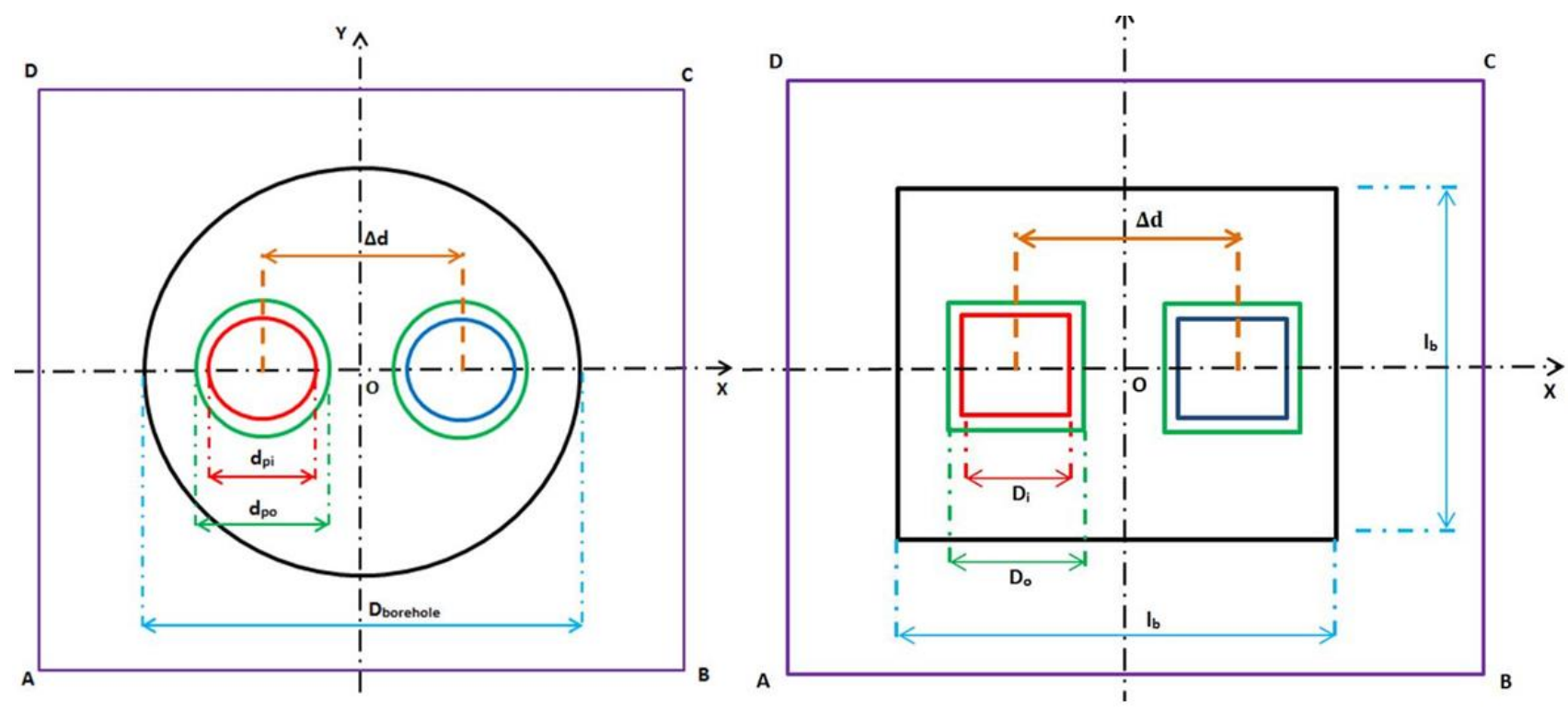

Fig.2. Schematic diagrams of equivalent pipe method

\subsubsection{Energy balance in solid region}

For heat transfer analysis, the EP is classified into two regions; solid region and fluid region. The solid region includes soil, grout and pipe, where heat transfer is regarded as three-dimensional transient heat conduction. The soil is divided into one hundred (100) layers in the vertical direction in order to interpret the effect of fluid temperature variation. Therefore, the energy balance equation of the soil domain is given as:

$\rho_{\text {soil }} \mathrm{c}_{\text {soil }} \frac{\partial \mathrm{T}_{\mathrm{s}}}{\partial \mathrm{t}}=\frac{\partial}{\partial \mathrm{x}}\left(\mathrm{k}_{\text {soil }} \frac{\partial \mathrm{T}_{\mathrm{s}}}{\partial \mathrm{x}}\right)+\frac{\partial}{\partial \mathrm{y}}\left(\mathrm{k}_{\text {soil }} \frac{\partial \mathrm{T}_{\mathrm{s}}}{\partial \mathrm{y}}\right)+\frac{\partial}{\partial \mathrm{z}}\left(\mathrm{k}_{\text {soil }} \frac{\partial \mathrm{T}_{\mathrm{s}}}{\partial \mathrm{z}}\right)$

Grout as heat transfer medium in energy pile has high thermal conductivity and storage capacity. Hence, energy balance equation of the backfill material (grout) domain is given as:

$\rho_{\text {grout }} \mathrm{c}_{\text {grout }} \frac{\partial \mathrm{T}_{\mathrm{g}}}{\partial \mathrm{t}}=\frac{\partial}{\partial \mathrm{x}}\left(\mathrm{k}_{\text {grout }} \frac{\partial \mathrm{T}_{\mathrm{g}}}{\partial \mathrm{x}}\right)+\frac{\partial}{\partial \mathrm{y}}\left(\mathrm{k}_{\text {grout }} \frac{\partial \mathrm{T}_{\mathrm{g}}}{\partial \mathrm{y}}\right)+\frac{\partial}{\partial \mathrm{z}}\left(\mathrm{k}_{\text {grout }} \frac{\partial \mathrm{T}_{\mathrm{g}}}{\partial \mathrm{z}}\right)$

Heat transfer through the pipe is treated as pure heat conduction as well, and defined as 3D heat conduction versus time. Thus, the corresponding energy conservation equation can be written as:

$\rho_{\text {pipe }} \mathrm{c}_{\text {pipe }} \frac{\partial \mathrm{T}_{\mathrm{p}}}{\partial \mathrm{t}}=\frac{\partial}{\partial \mathrm{x}}\left(\mathrm{k}_{\text {pipe }} \frac{\partial \mathrm{T}_{\mathrm{p}}}{\partial \mathrm{x}}\right)+\frac{\partial}{\partial \mathrm{y}}\left(\mathrm{k}_{\text {pipe }} \frac{\partial \mathrm{T}_{\mathrm{p}}}{\partial \mathrm{y}}\right)+\frac{\partial}{\partial \mathrm{z}}\left(\mathrm{k}_{\text {pipe }} \frac{\partial \mathrm{T}_{\mathrm{p}}}{\partial \mathrm{z}}\right)$

Where $\rho_{\text {soil, }}, \rho_{\text {grout }}$ and $\rho_{\text {pipe }}$ are the densities of soil, grout and pipe $\left(\mathrm{kg} / \mathrm{m}^{3}\right) ; \mathrm{c}_{\text {soil }}, \mathrm{c}_{\text {grout }}$ and $\mathrm{c}_{\text {pipe }}$ are the thermal capacities of soil, grout and pipe $(\mathrm{J} / \mathrm{kg} \cdot \mathrm{K}) ; \mathrm{k}_{\text {soil }}, \mathrm{k}_{\text {grout }}$ and $\mathrm{k}_{\text {pipe }}$ are the thermal conductivities of soil, grout and pipe $(\mathrm{W} / \mathrm{m} \cdot \mathrm{K}) ; \mathrm{T}_{\mathrm{s}}, \mathrm{T}_{\mathrm{g}}$ and $\mathrm{T}_{\mathrm{p}}$ are the temperatures of soil, grout and pipe $\left({ }^{\circ} \mathrm{C}\right)$ respectively.

2.1.3 Energy balance in fluid region 
In the fluid region, heat convection occurs between the rectangular pipe and working fluid. The fluid flow direction of inlet pipe is opposite to the direction of outlet pipe. Therefore, the energy balance equations of inlet pipe and outlet pipe need to be developed separately. Furthermore, the bottom connecting section is considered, where the average temperature of the upward flow fluid is equal to that of the downward flow fluid though the fluid velocities are equal $V_{1}=(-) V_{2}=(-) V$. The simplified modelling process is presented in Fig.3.

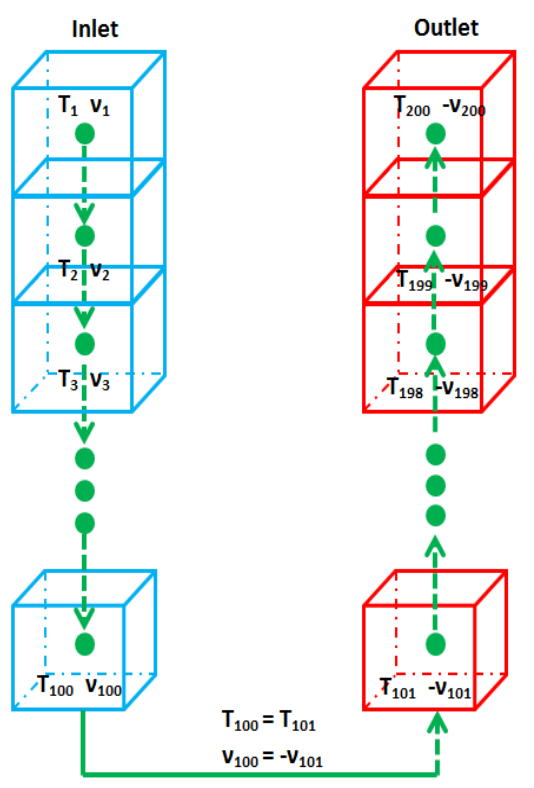

Fig.3. Graphical scheme of modelling fluid in the pipe loop

The fluid in the inlet pipe (downward flow) can be modelled as follows:

$\rho_{\text {fluid }} \mathrm{c}_{\text {fluid }} \frac{\partial \mathrm{T}_{\text {inlet }}}{\partial \mathrm{t}}+(\rho \mathrm{cv})_{\mathrm{f}} \frac{\partial \mathrm{T}_{\text {inlet }}}{\partial \mathrm{z}}=\mathrm{k}_{\text {fluid }} \frac{\partial^{2} \mathrm{~T}_{\text {inlet }}}{\partial \mathrm{z}^{2}}+\mathrm{b}_{\mathrm{ig}}\left(\mathrm{T}_{\text {grout }}-\mathrm{T}_{\text {inlet }}\right)$

Similarly, the fluid in the outlet pipe (upward flow) is also modelled as:

$\rho_{\text {fluid }} \mathrm{c}_{\text {fluid }} \frac{\partial \mathrm{T}_{\text {outlet }}}{\partial \mathrm{t}}+(\rho \mathrm{cv})_{\mathrm{f}} \frac{\partial \mathrm{T}_{\text {outlet }}}{\partial \mathrm{z}}=\mathrm{k}_{\text {fluid }} \frac{\partial^{2} \mathrm{~T}_{\text {outlet }}}{\partial \mathrm{z}^{2}}+\mathrm{b}_{\mathrm{og}}\left(\mathrm{T}_{\text {grout }}-\mathrm{T}_{\text {outlet }}\right)$

The left sides of Eqs. (14) and (15) denote the volumes of the specific components, and the right sides denote the contact surface regions for the interacting surfaces. Based on the simple model presented by Al-Khoury et al. [28-30], heat transfer coefficients of U-tube can be written as

$\mathrm{b}_{\mathrm{ig}}=\frac{1}{\mathrm{R}_{\mathrm{ig}}}, \mathrm{b}_{\mathrm{og}}=\frac{1}{\mathrm{R}_{\mathrm{og}}}$

$\mathrm{R}_{\mathrm{ig}}=\mathrm{R}_{\text {convection }}+\mathrm{R}_{\mathrm{pipe}}=\frac{1}{\frac{\mathrm{D}_{0} / 2}{\mathrm{D}_{\mathrm{i}} / 2 \cdot \mathrm{h}}}+\frac{\mathrm{D}_{0} \ln \left(\frac{\mathrm{D}_{0}}{\mathrm{D}_{\mathrm{i}}}\right)}{\mathrm{k}_{\text {pipe }}}$ 
Where $b_{i g}$ is the reciprocal of thermal resistance $R_{i g}$ between inlet pipe and grout $\left(\mathrm{W} / \mathrm{m}^{2} \cdot \mathrm{K}\right)$; $b_{\mathrm{og}}$ is the reciprocal of thermal resistance $\mathrm{R}_{\mathrm{og}}$ between outlet pipe and grout $\left(\mathrm{W} / \mathrm{m}^{2} \cdot \mathrm{K}\right)$; h is the convective heat transfer coefficient between working fluid and pipe material $\left(\mathrm{W} / \mathrm{m}^{2} \cdot \mathrm{K}\right)$.

\subsection{Multiple EP model}

The main problem with single energy pile is that it has limited heat transfer capacity thereby transferring limited heat to the building. In order to meet building energy requirement, the EP system is normally designed with multiple piles. The multiple energy piles model is shown in Fig.4. The red and blue regions represent the inlet and outlet pipes respectively whereas the green and gray regions indicate the grout and soil domains. The overall analysis region is defined by the isothermal boundary. The spatial coordinate is discretized and divided into two rectangular coordinate systems; horizontal (X-Y) and vertical (X-Z). At the horizontal level, more meshes are generated for the region adjacent to pile where the temperature gradient is larger, while fewer meshes are for far field boundary region where the temperature gradient is smaller. The equivalent grids are adopted in vertical direction.

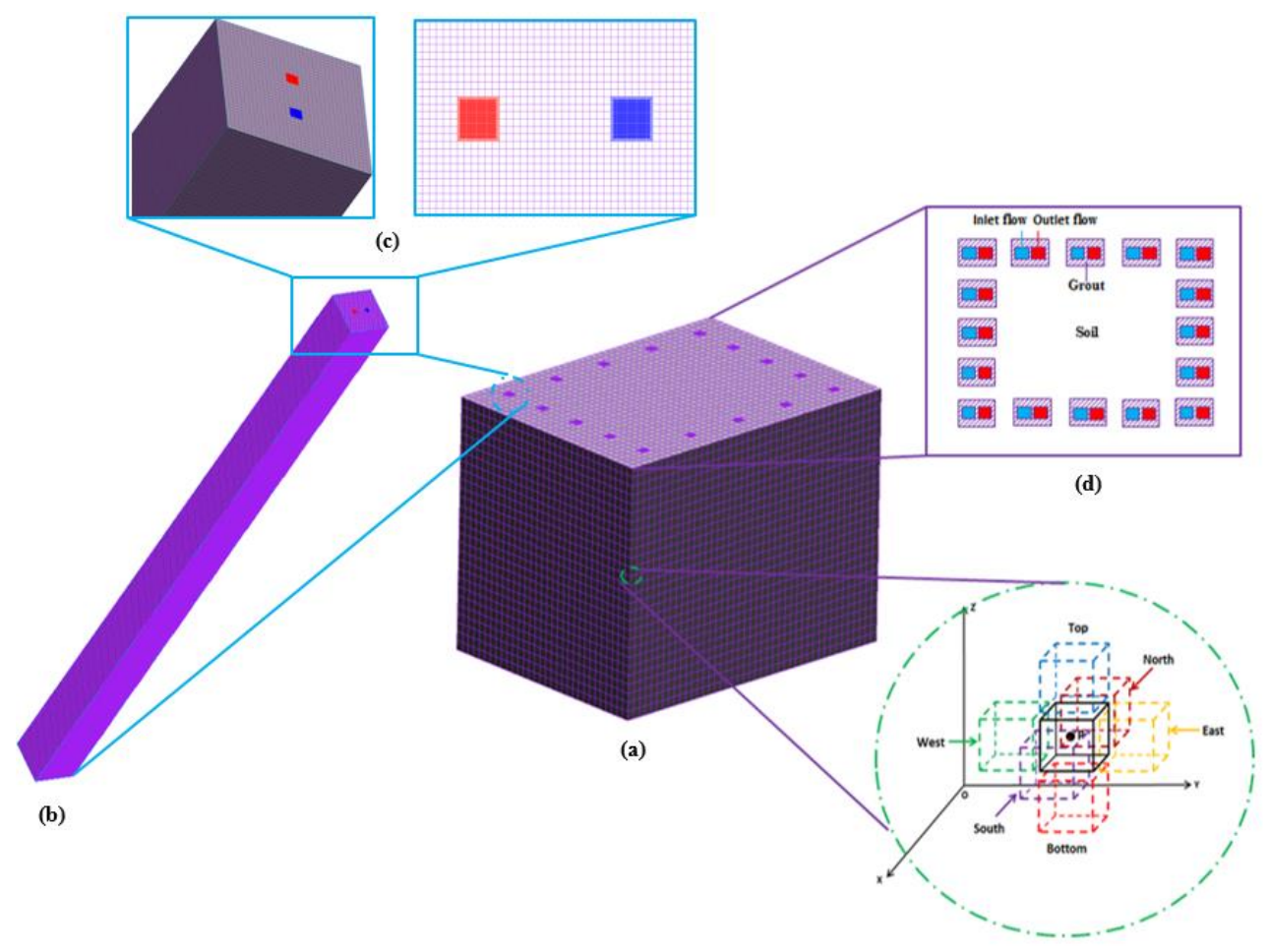

(e)

Fig.4. Schematic representation of discretised model: (a) 3D multiple EPs model (b) 3D single EP model (c) Top discretised cross-section of single model (d) Top discretised cross-section of multiple model (e) Arbitrary cube cell

The simulated region is discretized as a finite number of contiguous non-overlapping cell cubes. The computational nodes are located at the centre of each cell cube. The black cube (P point) in Fig.4 (e) is regarded as the control volume and its six neighboring nodes are identified as west, east, south, north, top and bottom in which the corresponding cell faces are denoted by 
$\mathrm{w}, \mathrm{e}, \mathrm{s}, \mathrm{n}, \mathrm{t}$ ' and $\mathrm{b}$ respectively. The governing equation is discretized through fully implicit approach whereby each pile is composed of a series of cubes in three different directions ( $x, y$ and $z)$. In a cube cell with a nodal point $P(\varphi, \omega, j)$ at the centre, $\varphi, \omega, \mathrm{j}$ denote a nodal point in direction of $\mathrm{x}$ axis, $\mathrm{y}$ axis and $\mathrm{z}$ axis, respectively.

Integration of Eq. (11)-(13) over the control volume and a time interval from $\mathrm{t}$ to $\mathrm{t}+\Delta \mathrm{t}$ gives

$\int_{C V}\left[\int_{t}^{t+\Delta t} \rho c \frac{\partial T}{\partial t} d t\right] d V=\int_{t}^{t+\Delta t}\left[\left(k A \frac{\partial T}{\partial x}\right)_{e}-\left(k A \frac{\partial T}{\partial x}\right)_{w}\right]+\int_{t}^{t+\Delta t}\left[\left(k A \frac{\partial T}{\partial y}\right)_{n}-\left(k A \frac{\partial T}{\partial y}\right)_{s}\right]+\int_{t}^{t+\Delta t}\left[\left(k A \frac{\partial T}{\partial z}\right)_{t^{\prime}}-\left(k A \frac{\partial T}{\partial z}\right)_{b}\right]$

Where, $\mathrm{A}$ is the face area of the control volume, $\mathrm{CV}$ is its control volume. Thereby, the left hand side of the volume integral of the temporal derivative can be written as

$\int_{C V}\left[\int_{t}^{t+\Delta t} \rho c \frac{\partial T}{\partial t} d t\right] d V=\rho c\left(T_{P}-T_{P}^{0}\right) \Delta V$

Where, $\frac{\partial \mathrm{T}}{\partial \mathrm{t}}=\frac{1}{\Delta \mathrm{t}}\left(\mathrm{T}_{\mathrm{P}}-\mathrm{T}_{\mathrm{P}}^{0}\right)$, this term has been discretised by a first-order (backward) differencing scheme, in which $\mathrm{T}_{\mathrm{P}}^{0}$ is the value of $\mathrm{T}$ at time $\mathrm{t}$ and $\mathrm{T}_{\mathrm{P}}$ is the value at time $\mathrm{t}+\Delta \mathrm{t}$, with $\Delta \mathrm{t}$ is the same time step, $\Delta \mathrm{V}=\mathrm{dxdydz}$.

The fully implicit discretisation method is applied to this proposed model, thereby the value of $\varepsilon$ is set equal to 1 .

$\mathrm{I}_{\mathrm{T}}=\int_{\mathrm{t}}^{\mathrm{t}+\Delta \mathrm{t}} \mathrm{T}_{\mathrm{p}} \mathrm{dt}=\left[\varepsilon \mathrm{T}_{\mathrm{p}}+(1-\varepsilon) \mathrm{T}_{\mathrm{p}}^{0}\right] \Delta \mathrm{t}$

Similarly, the fully implicit discretisation method for diffusion problems in Eq. (14) and (15) is also adopted.

The discretized equations of an internal node are given as:

$\Theta(\varphi, \omega, \mathrm{j}) \cdot \Gamma(\varphi, \omega, \mathrm{j}, \mathrm{t}+1)=$

$\Theta_{\mathrm{w}}(\varphi, \omega, \mathrm{j}) \cdot \Gamma(\varphi-1, \omega, \mathrm{j}, \mathrm{t}+1)+\Theta_{\mathrm{e}}(\varphi, \omega, \mathrm{j}) \cdot \Gamma(\varphi+1, \omega, \mathrm{j}, \mathrm{t}+1)$

$+\Theta_{\mathrm{s}}(\varphi, \omega, \mathrm{j}) \cdot \Gamma(\varphi, \omega-1, \mathrm{j}, \mathrm{t}+1)+\Theta_{\mathrm{n}}(\varphi, \omega, \mathrm{j}) \cdot \Gamma(\varphi, \omega+1, \mathrm{j}, \mathrm{t}+1)$

$+\Theta_{\mathrm{b}}(\varphi, \omega, \mathrm{j}) \cdot \Gamma(\varphi, \omega, \mathrm{j}-1, \mathrm{t}+1)+\Theta_{\mathrm{t}^{\prime}}(\varphi, \mathrm{n}, \mathrm{j}) \cdot \Gamma(\varphi, \omega, \mathrm{j}+1, \mathrm{t}+1)$

$+\Theta^{0}(\varphi, \omega, \mathrm{j}) \cdot \Gamma(\varphi, \omega, \mathrm{j}, \mathrm{t})$

Where, $\Gamma$ is temperature node of cell cube and the superscript " 0 " refers to the state at the initial time step. The corresponding coefficients $(\Theta)$ are expressed as:

$$
\begin{aligned}
& \Theta_{\mathrm{w}}(\varphi, \omega, \mathrm{j})=\frac{\mathrm{k}_{\mathrm{w}} \cdot \Delta \mathrm{y}_{\omega} \cdot \Delta \mathrm{z}_{\mathrm{j}}}{(\delta \mathrm{x})_{\mathrm{w}}}, \Theta_{\mathrm{e}}(\varphi, \omega, \mathrm{j})=\frac{\mathrm{k}_{\mathrm{e}} \cdot \Delta \mathrm{y}_{\omega} \cdot \Delta \mathrm{z}_{\mathrm{j}}}{(\delta \mathrm{x})_{\mathrm{e}}}, \Theta_{\mathrm{s}}(\varphi, \omega, \mathrm{j})=\frac{\mathrm{k}_{\mathrm{s}} \cdot \Delta \mathrm{x}_{\varphi} \cdot \Delta \mathrm{z}_{\mathrm{j}}}{(\delta \mathrm{y})_{\mathrm{s}}} \\
& \Theta_{\mathrm{n}}(\varphi, \omega, \mathrm{j})=\frac{\mathrm{k}_{\mathrm{n}} \cdot \Delta \mathrm{x}_{\varphi} \cdot \Delta \mathrm{z}_{\mathrm{j}}}{(\delta \mathrm{y})_{\mathrm{n}}}, \Theta_{\mathrm{b}}(\varphi, \omega, \mathrm{j})=\frac{\mathrm{k}_{\mathrm{b}} \cdot \Delta \mathrm{x}_{\varphi} \cdot \Delta \mathrm{y}_{\omega}}{(\delta \mathrm{z})_{\mathrm{b}}}, \Theta_{\mathrm{t}}(\varphi, \omega, \mathrm{j})=\frac{\mathrm{k}_{\mathrm{t}} \cdot \Delta \mathrm{x}_{\varphi} \cdot \Delta \mathrm{y}_{\omega}}{(\delta)_{\mathrm{t}^{\prime}}}
\end{aligned}
$$


$\Theta^{0}(\varphi, \omega, j)=\frac{c \cdot \rho \cdot \Delta x_{\varphi} \cdot \Delta y_{\omega} \cdot \Delta z_{j}}{\Delta t}$

$\Theta(\varphi, \omega, \mathbf{j})=\Theta_{w}(\varphi, \omega, \mathbf{j})+\Theta_{\mathrm{e}}(\varphi, \omega, \mathrm{j})+\Theta_{\mathrm{s}}(\varphi, \omega, \mathrm{j})+\Theta_{\mathrm{n}}(\varphi, \omega, \mathrm{j})+\Theta_{\mathrm{b}}(\varphi, \omega, \mathrm{j})+\Theta_{\mathrm{t}^{\prime}}(\varphi, \omega, \mathrm{j})+\Theta^{0}(\varphi, \omega, \mathrm{j})$

\section{Boundary and initial conditions}

\subsection{Boundary conditions}

Boundary conditions are classified into two categories: first and second boundary conditions. The first boundary condition is expressed in terms of temperature at the boundary while the second is expressed in terms of temperature gradient. In the case of the first boundary condition, at $\mathrm{z}=0$, the inlet pipe temperature is equal to the fluid temperature i.e.;

$\mathrm{T}_{\text {inlet }}(0, \mathrm{t})=\mathrm{T}_{\text {fluid }}(\mathrm{t})$

In terms of the second boundary condition, at $\mathrm{z}=0$, heat flux at the exit of outlet pipe is depicted as:

$$
\frac{\partial \mathrm{T}_{\text {outlet }}(0, \mathrm{t})}{\partial \mathrm{z}}=0
$$

For the conjugated surface between fluid and pipe:

Inlet pipe:

$$
\begin{aligned}
& \left.\mathrm{h}_{\mathrm{s}}\left[\mathrm{T}_{\mathrm{f} 1}^{\text {inlet }}-\mathrm{T}_{\text {pipe }}^{\text {inner }}(\mathrm{x}, \mathrm{y})\right]\right|_{\mathrm{x}=-\frac{\Delta d \pm \mathrm{D}_{\mathrm{i}}}{2},-\frac{\mathrm{D}_{i}}{2} \leq y \leq \frac{\mathrm{D}_{\mathrm{i}}}{2}}=\left.\mathrm{k}_{\text {pipe }} \frac{\partial \mathrm{T}_{\text {pipe }}}{\partial \mathrm{x}}\right|_{x=-\frac{\Delta d \pm \mathrm{D}_{\mathrm{i}}}{2},-\frac{\mathrm{D}_{\mathrm{i}}}{2} \leq y \leq \frac{\mathrm{D}_{\mathrm{i}}}{2}}
\end{aligned}
$$

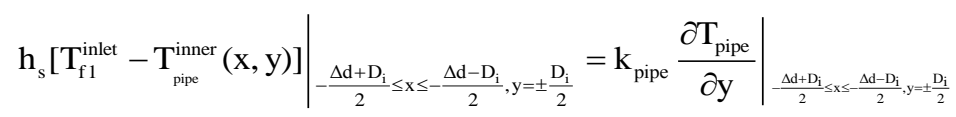

Outlet pipe:

$$
\begin{aligned}
& \left.\mathrm{h}_{\mathrm{s}}\left[\mathrm{T}_{\mathrm{f} 2}^{\text {outlet }}-\mathrm{T}_{\text {pipe }}^{\text {inner }}(\mathrm{x}, \mathrm{y})\right]\right|_{\mathrm{x}=-\frac{\Delta d \pm \mathrm{D}_{\mathrm{i}},-\frac{\mathrm{D}_{\mathrm{i}}}{2} \leq y \leq \frac{\mathrm{D}_{\mathrm{i}}}{2}}{2}}=\left.\mathrm{k}_{\text {pipe }} \frac{\partial \mathrm{T}_{\text {pipe }}}{\partial \mathrm{x}}\right|_{x=-\frac{\Delta d \pm \mathrm{D}_{\mathrm{i}}}{2},-\frac{\mathrm{D}_{\mathrm{i}}}{2} \leq y \leq \frac{\mathrm{D}_{\mathrm{i}}}{2}}
\end{aligned}
$$

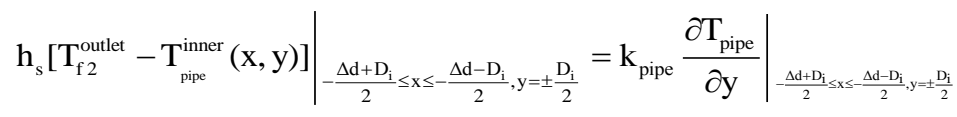

For the conjugated surface between pipe and grout:

Inlet pipe:

$$
\begin{aligned}
& \left.\mathrm{k}_{\text {pipe }} \frac{\partial \mathrm{T}_{\text {pipe }}}{\partial \mathrm{x}}\right|_{x=-\frac{\Delta \mathrm{d} \pm \mathrm{D}_{\mathrm{o}}}{2},-\frac{\mathrm{D}_{\mathrm{o}}}{2} \leq y \leq \frac{\mathrm{D}_{\mathrm{o}}}{2}}=\left.\mathrm{k}_{\mathrm{borehole}} \frac{\partial \mathrm{T}_{\text {borehole }}}{\partial \mathrm{x}}\right|_{x=-\frac{\Delta \mathrm{d} \pm \mathrm{D}_{\mathrm{o}}}{2},-\frac{\mathrm{D}_{\mathrm{o}}}{2} \leq y \leq \frac{\mathrm{D}_{\mathrm{o}}}{2}} \\
& \left.\mathrm{~T}_{\text {pipe }}\right|_{x=-\frac{\Delta \mathrm{d} \pm \mathrm{D}_{\mathrm{o}}}{2},-\frac{\mathrm{D}_{\mathrm{o}}}{2} \leq y \leq \frac{\mathrm{D}_{\mathrm{o}}}{2}}=\left.\mathrm{T}_{\text {borehole }}\right|_{x=-\frac{\Delta \mathrm{d} \pm \mathrm{D}_{\mathrm{o}}}{2},-\frac{\mathrm{D}_{\mathrm{o}}}{2} \leq y \leq \frac{\mathrm{D}_{\mathrm{o}}}{2}}
\end{aligned}
$$




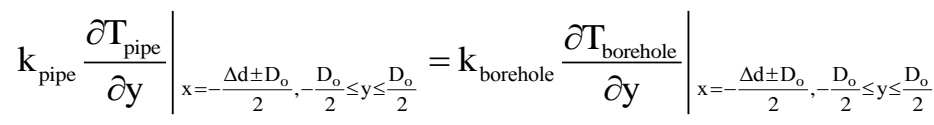

$\mathrm{T}_{\text {pipe }}\left|-\frac{\Delta \mathrm{d}+\mathrm{D}_{\mathrm{o}}}{2} \leq \mathrm{x} \leq-\frac{\Delta \mathrm{d}-\mathrm{D}_{\mathrm{o}}, \mathrm{y}=\frac{\mathrm{D}_{\mathrm{o}}}{2}}{2}=\mathrm{T}_{\text {borehole }}\right|-\frac{\Delta \mathrm{d}+\mathrm{D}_{\mathrm{o}}}{2} \leq \mathrm{x} \leq-\frac{\Delta \mathrm{d}-\mathrm{D}_{\mathrm{o}}}{2}, \mathrm{y}= \pm \frac{\mathrm{D}_{\mathrm{o}}}{2}$

Outlet pipe:

$\left.\mathrm{k}_{\text {pipe }} \frac{\partial \mathrm{T}_{\text {pipe }}}{\partial \mathrm{x}}\right|_{x=\frac{\Delta \mathrm{d} \pm \mathrm{D}_{\mathrm{o}}}{2},-\frac{\mathrm{D}_{\mathrm{o}}}{2} \leq \mathrm{y} \leq \frac{\mathrm{D}_{\mathrm{o}}}{2}}=\left.\mathrm{k}_{\text {borehole }} \frac{\partial \mathrm{T}_{\text {borehole }}}{\partial \mathrm{x}}\right|_{x=\frac{\Delta \mathrm{d} \pm \mathrm{D}_{\mathrm{o}}}{2},-\frac{\mathrm{D}_{\mathrm{o}}}{2} \leq \mathrm{y} \leq \frac{\mathrm{D}_{\mathrm{o}}}{2}}$

$\left.\mathrm{T}_{\text {pipe }}\right|_{\mathrm{x}=\frac{\Delta \mathrm{d} \pm \mathrm{D}_{\mathrm{o}}}{2},-\frac{\mathrm{D}_{\mathrm{o}}}{2} \leq y \leq \frac{\mathrm{D}_{\mathrm{O}}}{2}}=\left.\mathrm{T}_{\text {borehole }}\right|_{\mathrm{x}=\frac{\Delta \mathrm{d} \pm \mathrm{D}_{\mathrm{o}}}{2},-\frac{\mathrm{D}_{\mathrm{o}}}{2} \leq y \leq \frac{\mathrm{D}_{\mathrm{o}}}{2}}$

$\left.\mathrm{k}_{\text {pipe }} \frac{\partial \mathrm{T}_{\text {pipe }}}{\partial \mathrm{y}}\right|_{-\frac{\Delta \mathrm{d}+\mathrm{D}_{\mathrm{o}}}{2} \leq \mathrm{x} \leq-\frac{\Delta \mathrm{d}-\mathrm{D}_{\mathrm{o}}}{2}, \mathrm{y} \pm \pm \frac{\mathrm{D}_{\mathrm{o}}}{2}}=\left.\mathrm{k}_{\text {borehole }} \frac{\partial \mathrm{T}_{\text {borehole }}}{\partial \mathrm{y}}\right|_{-\frac{\Delta \mathrm{d}+\mathrm{D}_{\mathrm{o}}}{2} \leq x \leq-\frac{\Delta \mathrm{d}-\mathrm{D}_{\mathrm{o}}}{2}, \mathrm{y}= \pm \frac{\mathrm{D}_{\mathrm{o}}}{2}}$

$\mathrm{T}_{\text {pipe }}\left|-\frac{\Delta \mathrm{d}+\mathrm{D}_{\mathrm{o}}}{2} \leq \mathrm{x} \leq-\frac{\Delta \mathrm{d}-\mathrm{D}_{\mathrm{o}}, \mathrm{y}= \pm \frac{\mathrm{D}_{\mathrm{o}}}{2}}{2}=\mathrm{T}_{\text {borehole }}\right|-\frac{\Delta \mathrm{d}+\mathrm{D}_{\mathrm{o}}}{2} \leq \mathrm{x} \leq-\frac{\Delta \mathrm{d}-\mathrm{D}_{\mathrm{o}}}{2}, \mathrm{y}= \pm \frac{\mathrm{D}_{\mathrm{o}}}{2}$

For the conjugated surface between grout and soil:

$\left.\mathrm{k}_{\text {borehole }} \frac{\partial \mathrm{T}_{\text {borehole }}}{\partial \mathrm{x}}\right|_{x= \pm \pm \frac{1_{b}}{2},-\frac{1_{b}}{2} \leq y \leq \frac{1_{b}}{2}}=\left.\mathrm{k}_{\text {soil }} \frac{\partial T_{\text {soil }}}{\partial x}\right|_{x= \pm \frac{1}{2},-\frac{1_{b}}{2} \leq y \leq \frac{1}{2}}$

$\left.T_{\text {borehole }}\right|_{x=\frac{\Delta d \pm D_{0}}{2},-\frac{D_{0}}{2} \leq y \leq \frac{D_{0}}{2}}=\left.T_{\text {soil }}\right|_{x=\frac{\Delta d \pm D_{0}}{2},-\frac{D_{0}}{2} \leq y \leq \frac{D_{0}}{2}}$

$\left.\mathrm{k}_{\text {borehole }} \frac{\partial \mathrm{T}_{\text {borehole }}}{\partial \mathrm{x}}\right|_{-\frac{\mathrm{l}_{\mathrm{b}}}{2} \leq x \leq \frac{\mathrm{l}_{\mathrm{b}}, y= \pm \frac{1_{\mathrm{b}}}{2}}{2}}=\left.\mathrm{k}_{\text {soil }} \frac{\partial \mathrm{T}_{\text {soil }}}{\partial \mathrm{y}}\right|_{-\frac{\mathrm{b}}{2} \leq x \leq \frac{1_{\mathrm{b}}}{2}, y= \pm \frac{1_{\mathrm{b}}}{2}}$

$\left.\mathrm{T}_{\text {borehole }}\right|_{-\frac{b_{b}}{2} \leq x \leq \frac{1_{b}}{2}, y=-\frac{b_{b}}{2}}=\left.\mathrm{T}_{\text {soil }}\right|_{-\frac{b_{b}}{2} \leq x \leq \frac{b_{b}}{2}, y= \pm \frac{1}{2}}$

For the conjugated surface at the bottom of soil domain:

$\left.\mathrm{k}_{\text {soil }} \frac{\partial \mathrm{T}_{\text {soil }}}{\partial \mathrm{z}}\right|_{\mathrm{z}=-\mathrm{L}+3}=0$

For the bottom connecting section between inlet and outlet pipes:

$\mathrm{T}_{\mathrm{f} 1}(\mathrm{z}=-\mathrm{L}, \mathrm{t})=\mathrm{T}_{\mathrm{f} 2}(\mathrm{z}=-\mathrm{L}, \mathrm{t})$

For the ground surface boundary condition: 
$-\left.\mathrm{k}_{\text {borehole }} \frac{\partial \mathrm{T}_{\text {borehole }}}{\partial \mathrm{z}}\right|_{\mathrm{z}=0}=\left.\mathrm{h}_{\text {air }}\left[\mathrm{T}_{\text {air }}-\mathrm{T}_{\text {borehole }}\right]\right|_{\mathrm{z}=0}$

$-\left.\mathrm{k}_{\text {soil }} \frac{\partial \mathrm{T}_{\text {soil }}}{\partial \mathrm{z}}\right|_{\mathrm{z}=0}=\left.\mathrm{h}_{\text {air }}\left[\mathrm{T}_{\text {air }}-\mathrm{T}_{\text {soil }}\right]\right|_{\mathrm{z}=0}$

Where $\mathrm{T}_{\text {pipe }}, \mathrm{T}_{\text {borehole }}, \mathrm{T}_{\text {soil }}$ are the temperatures of pipe, borehole and soil $\left({ }^{\circ} \mathrm{C}\right) ; \mathrm{T}_{\mathrm{f} 1}, \mathrm{~T}_{\mathrm{f} 2}$ are the working fluid temperatures within the inlet and outlet pipes; $\mathrm{L}$ is the EP depth $(\mathrm{m}) ; \mathrm{h}_{\text {air }}$ is the heat convection coefficient between ambient air and ground surface $(\mathrm{W} / \mathrm{m} \cdot \mathrm{K}) ; \mathrm{T}_{\text {air }}$ is the ambient air temperature $\left({ }^{\circ} \mathrm{C}\right)$.

\subsection{Initial conditions}

At the start point $(\mathrm{t}=0)$, the temperatures of working fluid, pipe, grout and soil are equal in the system. The initial state is shown as follows:

$\mathrm{T}_{\text {fluid }}(\mathrm{z}, \mathrm{t})=\mathrm{T}_{\text {pipe }}(\mathrm{x}, \mathrm{y}, \mathrm{z}, \mathrm{t})=\mathrm{T}_{\text {grout }}(\mathrm{x}, \mathrm{y}, \mathrm{z}, \mathrm{t})=\mathrm{T}_{\text {soil }}(\mathrm{x}, \mathrm{y}, \mathrm{z}, \mathrm{t}) \quad(\mathrm{t}=0)$

Where, $\mathrm{T}_{\text {fluid }}(\mathrm{z}, \mathrm{t})$ is the fluid temperature $\left({ }^{\circ} \mathrm{C}\right) ; \mathrm{T}_{\text {pipe }}(\mathrm{x}, \mathrm{y}, \mathrm{z}, \mathrm{t})$ is the pipe temperature $\left({ }^{\circ} \mathrm{C}\right) ; \mathrm{T}_{\text {grout }}(\mathrm{x}, \mathrm{y}, \mathrm{z}, \mathrm{t})$ is the grout temperature $\left({ }^{\circ} \mathrm{C}\right) ; \mathrm{T}_{\text {soil }}(\mathrm{x}, \mathrm{y}, \mathrm{z}, \mathrm{t})$ is the soil temperature $\left({ }^{\circ} \mathrm{C}\right)$. These initial conditions are listed in Table 1 .

Soil surface temperature $\mathrm{T}_{\text {soil }}(\mathrm{x}, \mathrm{y}, \mathrm{z}, 0)$ is treated as the undisturbed ground temperature. The ground temperature is a sinusoidal wave function of time and depth [42-44], and shown as below:

$\mathrm{T}_{\text {soil }}\left(\mathrm{Z}, \mathrm{t}_{\text {year }}\right)=\mathrm{T}_{\text {mean }}-\mathrm{T}_{\text {amp }} \cdot \exp \left(-\mathrm{Z} \times \sqrt{\frac{\pi}{365}}\right) \cdot \cos \left[\frac{2 \pi}{365} \cdot\left(\mathrm{t}_{\text {year }}-\mathrm{t}_{\text {shift }}-\frac{\mathrm{Z}}{2} \times \sqrt{\frac{365}{\pi \cdot \alpha}}\right)\right]$

Where $\mathrm{T}_{\text {soil }}\left(\mathrm{Z}, \mathrm{t}_{\text {year }}\right)$ is the undisturbed ground temperature at time $(\mathrm{t})$ and depth $(\mathrm{Z})\left({ }^{\circ} \mathrm{C}\right)$; $\mathrm{T}_{\text {mean }}$ is the mean surface temperature (average air temperature) $\left({ }^{\circ} \mathrm{C}\right) ; \mathrm{T}_{\mathrm{amp}}$ is the amplitude of surface temperature [(maximum air temperature - minimum air temperature)/2] $\left({ }^{\circ} \mathrm{C}\right) ; \mathrm{Z}$ is the depth below the surface $($ surface $=0)(\mathrm{m}) ; \alpha$ is the thermal conductivity of soil $(\mathrm{J} / \mathrm{kg} \cdot \mathrm{K}) ; \mathrm{t}_{\mathrm{year}}$ is the current time (day); $t_{\text {shift }}$ is the day of the year when the coldest air temperature occurs.

Table 1 Initial conditions and geometrical parameters

\begin{tabular}{|c|c|}
\hline Description & Value \\
\hline Pipe outside diameter $\left(d_{p o}\right)$ & $0.032 \mathrm{~m}$ \\
\hline Pipe inside diameter $\left(d_{p i}\right)$ & $0.013 \mathrm{~m}$ \\
\hline Shank spacing $(\Delta d)$ & $0.06 \mathrm{~m}$ \\
\hline EP diameter (DBorehole) & $0.3 \mathrm{~m}$ \\
\hline EP depth $(H)$ & $10 \mathrm{~m}$ \\
\hline Initial ground surface temperature ( $\left.T_{\text {surface }}\right)$ & $10.4^{\circ} \mathrm{C}$ \\
\hline Soil body temperature (soil far field boundary) ( $\mathbf{T}_{\text {soil body }}$ ) & $15.0{ }^{\circ} \mathrm{C}$ \\
\hline $\begin{array}{l}\text { Soil bottom temperature (soil far field boundary) } \\
\left.\text { ( } \mathbf{T}_{\text {soil bottom }}\right)\end{array}$ & $15.5^{\circ} \mathrm{C}$ \\
\hline Fluid Inlet Temperature $\left(\mathbf{T}_{\mathrm{fl}, \text { in }}\right)$ & $1.2^{\circ} \mathrm{C}$ \\
\hline
\end{tabular}




\section{Methodology}

The solution flowchart for the developed model is shown in Fig.5. The basic geometrical parameters, initial and boundary conditions are the main input data. The process begins with the equivalent model given by Eqs. (1)-(10). The iterative time is initiated with a value of $\Delta t$. The nodal temperatures in the equivalent cube are calculated at each step until the time required for the fluid to flow through the pile heat exchanger is reached. The related parameters including temperature and heat transfer rate are obtained in the process. After that, the program will stop and output the simulation data if the results meet the precision requirement, otherwise the time $\mathrm{t}$ will be iterated $(\mathrm{t}=\mathrm{t}+\Delta \mathrm{t})$ and the simulation process starts again. In this study, the simulation is carried out by an Intel 2 Duo $3 \mathrm{GHz}$ processor with 64 bit operation system, one step calculation would take approximately 25s for proposed model compared with typical 3D CFD model which require around $75 \mathrm{~s}$, a significant decrease of computational time with a good precision makes the proposed 3D model extremely useful. 


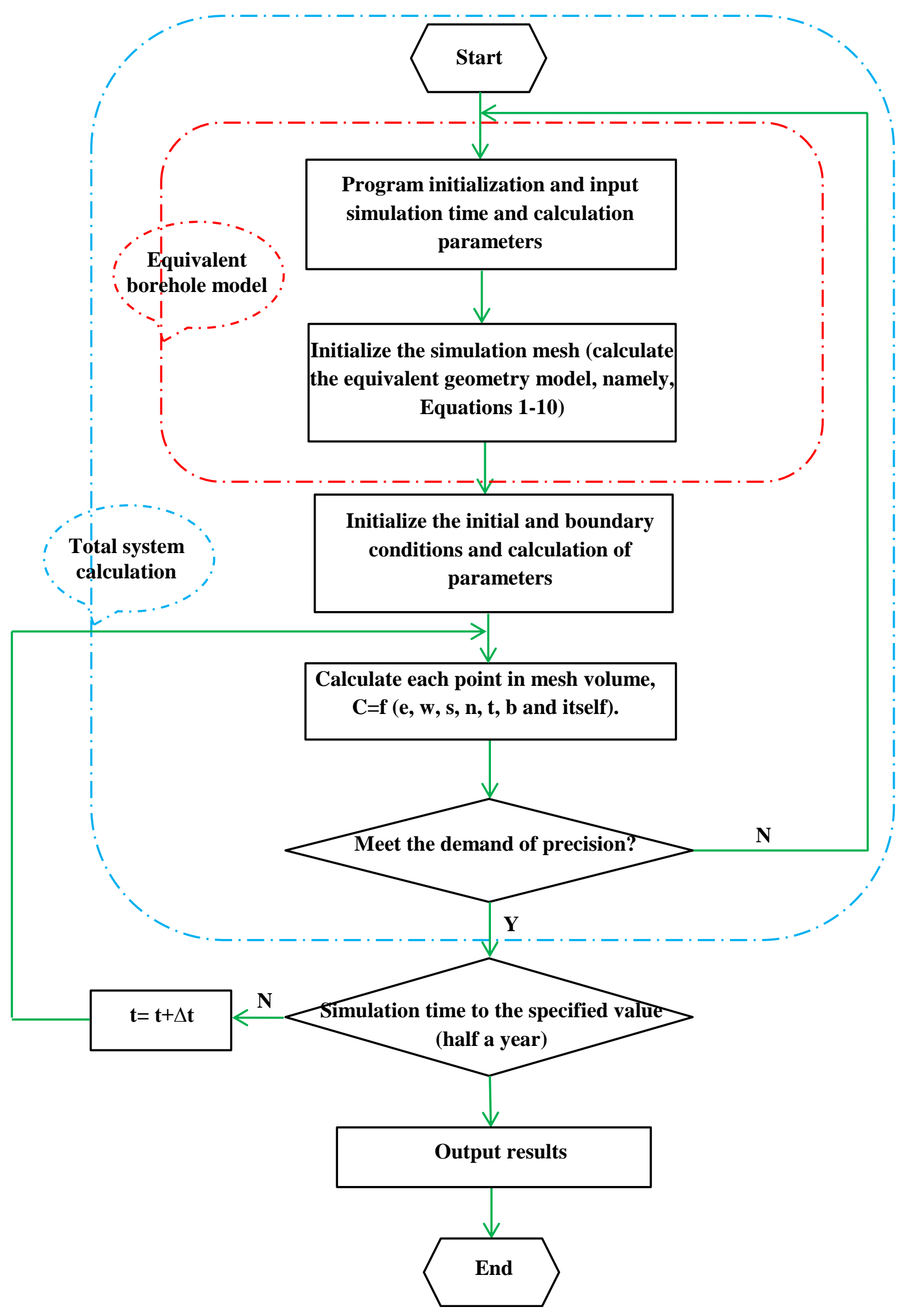

Fig.5. Flowchart of the computational procedure 


\section{Results and discussion}

Experimental results obtained from the facility near Birmingham, UK, are used to validate the numerical model, and the impacts of main parameters on the EP system performance are analyzed. The experimental multiple EPs were installed by Roger Bullivant Ltd [1, 27], as shown in Fig.6.

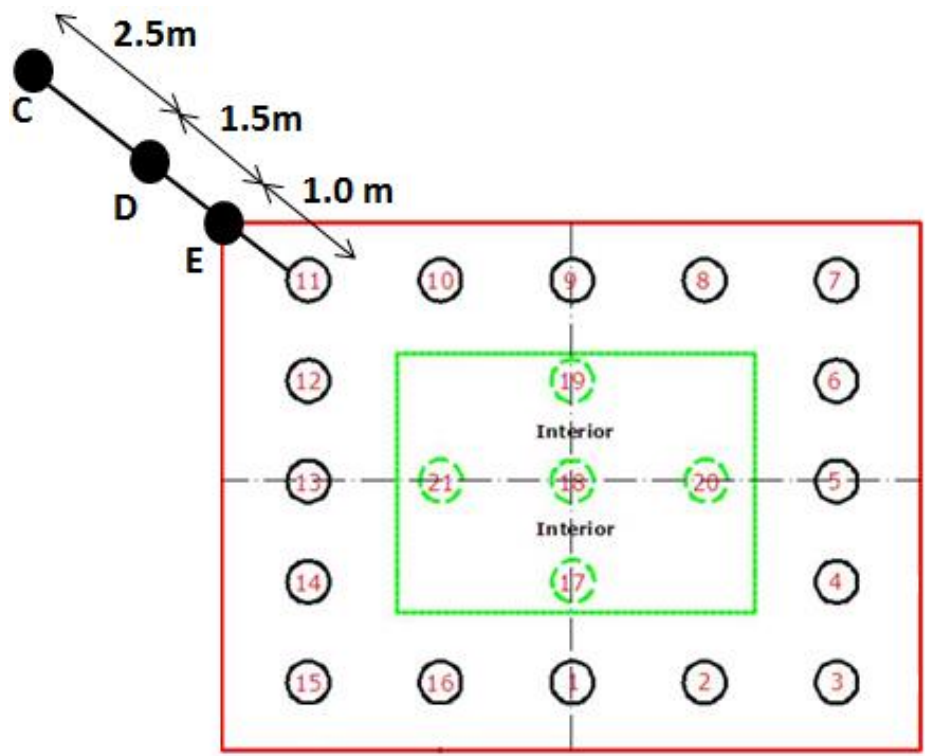

Fig.6. The schematic diagram of pile and thermocouple array layout

The total number of piles set up is 21 , which would be essential for the foundation requirement of a dwelling. However, only the perimeter 16 piles are utilized for heat exchange with soil. A number of $\mathrm{K}$ type thermocouples are adopted in the experimental system, each pile has a thermocouple located at the pile end. Moreover, thermocouples are also placed at locations C, D and E diagonally towards pile 11 to get ground temperatures. Data Taker DT505 is used to record the data output from these thermocouples. Turbine Hall Effect meters and platinum RTD PT100 probes are used to measure the working fluid flow rates and temperatures respectively [1, 27]. Table 2 lists the EP thermal properties in the experimental system.

Table 2 Thermal and physical properties used in the experimental system

\begin{tabular}{|l|l|}
\hline Description & Value \\
\hline Fluid (mixture of glycol and water) & \\
\hline Density $\left(\boldsymbol{\rho}_{\mathbf{f l}}\right)$ & $1035 \mathrm{~kg} / \mathrm{m}^{3}$ \\
\hline Kinematic viscosity $\left(\mathbf{v}_{\mathbf{f l}}\right)$ & $4.94 \times 10^{-6} \mathrm{~m}^{2} / \mathrm{s}$ \\
\hline Heat capacity $\left(\mathbf{C}_{\mathbf{p}, \mathbf{f l}}\right)$ & $3795 \mathrm{~J} /(\mathrm{kg} \cdot \mathrm{K})$ \\
\hline Thermal conductivity $\left(\mathbf{k}_{\mathbf{f l}}\right)$ & $0.58 \mathrm{~W} /(\mathrm{m} \cdot \mathrm{K})$ \\
\hline Pipe$($ High density polyethylene) & \\
\hline Density $\left(\boldsymbol{\rho}_{\mathbf{p}}\right)$ & $950 \mathrm{~kg} / \mathrm{m}^{3}$ \\
\hline Heat capacity $\left(\mathbf{C}_{\mathbf{p l}}\right)$ & $2300 \mathrm{~J} /(\mathrm{kg} \cdot \mathrm{K})$ \\
\hline Thermal conductivity $\left(\mathbf{k}_{\mathbf{p}}\right)$ & $0.45 \mathrm{~W} /(\mathrm{m} \cdot \mathrm{K})$ \\
\hline Filling $(\mathbf{G r o u t})$ & \\
\hline Density $\left(\boldsymbol{\rho}_{\mathbf{g}}\right)$ & $1860 \mathrm{~kg} / \mathrm{m}^{3}$ \\
\hline Heat capacity $\left(\mathbf{C}_{\mathbf{g}}\right)$ & $840 \mathrm{~J} /(\mathrm{kg} \cdot \mathrm{K})$ \\
\hline
\end{tabular}




\begin{tabular}{|l|l|l|l|}
\hline \multicolumn{2}{|l|}{ Thermal conductivity $\left(\mathrm{k}_{\mathbf{g}}\right)$} & $2 \mathrm{~W} /(\mathrm{m} \cdot \mathrm{K})$ \\
\hline \multirow{5}{*}{ Soil } & Depth & Thermal conductivity & Density \\
\cline { 2 - 4 } & Mixed gravel and coarse sand $\mathbf{0} \mathbf{~ m}$ to $\mathbf{2 . 2 2} \mathbf{~ m}$ & $1.30 \mathrm{~W} /(\mathrm{m} \cdot \mathrm{K})$ & $2277 \mathrm{~kg} / \mathrm{m}^{3}$ \\
\cline { 2 - 4 } & Sand gravel $\mathbf{2 . 2 2} \mathbf{m}$ to $3.3 \mathrm{~m}$ & $1.15 \mathrm{~W} /(\mathrm{m} \cdot \mathrm{K})$ & $2094 \mathrm{~kg} / \mathrm{m}^{3}$ \\
\cline { 2 - 4 } & Gravelly clay $\mathbf{3 . 3 m}$ to $\mathbf{5 . 5} \mathbf{~ m}$ & $1.68 \mathrm{~W} /(\mathrm{m} \cdot \mathrm{K})$ & $2223 \mathrm{~kg} / \mathrm{m}^{3}$ \\
\cline { 2 - 4 } & Gravelly clay $\mathbf{5 . 5 m}$ to $\mathbf{1 0} \mathbf{~ m}$ & $1.75 \mathrm{~W} /(\mathrm{m} \cdot \mathrm{K})$ & $2392 \mathrm{~kg} / \mathrm{m}^{3}$ \\
\cline { 2 - 4 } & Weighted mean & $1.50 \mathrm{~W} /(\mathrm{m} \cdot \mathrm{K})$ & $2260 \mathrm{~kg} / \mathrm{m}^{3}$ \\
\hline
\end{tabular}

The numerical results are compared with the experimental data in order to validate the $3 \mathrm{D}$ model, the errors between them are obtained by the following equation.

Error $=\left|\frac{\mathrm{T}_{\text {numerical }}-\mathrm{T}_{\text {experiment }}}{\mathrm{T}_{\text {numerical }}}\right|$

The errors for the working fluid, pile and soil temperatures in this study are summarized in Table 3 , it can be seen that the maximum error is $14.5 \%$ noticed in pile 13 , all average errors are blow $8 \%$, therefore the developed model is effectively supported by the experimental data, the detail error analyses are addressed in the following three subsections.

Table 3 Relative errors between 3D numerical and experimental results

\begin{tabular}{|c|c|c|c|c|c|c|c|c|c|c|c|c|c|c|c|}
\hline \multicolumn{4}{|c|}{ Outlet fluid temperature } & \multicolumn{4}{|c|}{ Soil temperature at location $\mathrm{C}$} & \multicolumn{4}{|c|}{ Soil temperature at location D } & \multicolumn{4}{|c|}{ Soil temperature at location $\mathbf{E}$} \\
\hline $\begin{array}{l}\text { Time } \\
\text { (hrs) }\end{array}$ & $\begin{array}{l}\text { Model } \\
\text { result } \\
\left({ }^{\circ} \mathrm{C}\right)\end{array}$ & $\begin{array}{c}\text { Test } \\
\text { result } \\
\left({ }^{\circ} \mathrm{C}\right)\end{array}$ & $\begin{array}{c}\text { Error } \\
(\%)\end{array}$ & $\begin{array}{l}\text { Time } \\
\text { (hrs) }\end{array}$ & $\begin{array}{l}\text { Model } \\
\text { result } \\
\left({ }^{\circ} \mathrm{C}\right)\end{array}$ & $\begin{array}{c}\text { Test } \\
\text { result } \\
\left({ }^{\circ} \mathrm{C}\right)\end{array}$ & $\begin{array}{c}\text { Error } \\
(\%)\end{array}$ & $\begin{array}{l}\text { Time } \\
\text { (hrs) }\end{array}$ & $\begin{array}{l}\text { Model } \\
\text { result } \\
\left({ }^{\circ} \mathrm{C}\right)\end{array}$ & $\begin{array}{c}\text { Test } \\
\text { result } \\
\left({ }^{\circ} \mathrm{C}\right)\end{array}$ & $\begin{array}{c}\text { Error } \\
(\%)\end{array}$ & $\begin{array}{l}\text { Time } \\
\text { (hrs) }\end{array}$ & $\begin{array}{c}\text { Model } \\
\text { result } \\
\left({ }^{\circ} \mathrm{C}\right)\end{array}$ & $\begin{array}{c}\text { Test } \\
\text { result } \\
\left({ }^{\circ} \mathrm{C}\right)\end{array}$ & $\begin{array}{c}\text { Error } \\
(\%)\end{array}$ \\
\hline 0 & 7.51 & 6.85 & 8.8 & 0 & 10.78 & 11.01 & 2.1 & 0 & 12.44 & 12.51 & 0.6 & 0 & 12.24 & 12.51 & 2.2 \\
\hline 24 & 6.80 & 6.25 & 8.1 & 408 & 10.82 & 10.98 & 1.5 & 408 & 12.39 & 12.45 & 0.5 & 408 & 12.17 & 12.47 & 2.5 \\
\hline 48 & 6.09 & 5.82 & 4.4 & 1560 & 10.91 & 11.08 & 1.6 & 1200 & 12.27 & 12.38 & 0.9 & 888 & 12.01 & 12.41 & 3.3 \\
\hline 72 & 5.56 & 5.53 & 0.5 & 2208 & 11.02 & 10.42 & 5.4 & 1800 & 12.25 & 12.61 & 2.9 & 1320 & 12.01 & 12.37 & 3.0 \\
\hline 224 & 4.45 & 4.49 & 0.9 & 2400 & 11.03 & 10.23 & 7.3 & 2640 & 12.15 & 12.23 & 0.7 & 1440 & 12.00 & 12.31 & 2.6 \\
\hline 408 & 4.31 & 4.33 & 0.5 & 2640 & 11.01 & 10.51 & 4.5 & 4128 & 12.03 & 12.24 & 1.8 & 3720 & 11.88 & 11.27 & 5.1 \\
\hline 528 & 4.18 & 4.19 & 0.2 & 3720 & 11.01 & 10.35 & 6.0 & 4320 & 12.01 & 12.10 & 0.8 & 3792 & 11.86 & 11.33 & 4.8 \\
\hline 552 & 4.10 & 4.11 & 0.2 & 4500 & 10.98 & 10.92 & 0.6 & 4500 & 12.01 & 12.03 & 0.2 & 4500 & 11.84 & 11.64 & 1.7 \\
\hline \multicolumn{4}{|c|}{ Pile 10 temperature } & \multicolumn{4}{|c|}{ Pile 11 temperature } & \multicolumn{4}{|c|}{ Pile 12 temperature } & \multicolumn{4}{|c|}{ Pile 13 temperature } \\
\hline $\begin{array}{l}\text { Time } \\
\text { (hrs) }\end{array}$ & $\begin{array}{c}\text { Model } \\
\text { result } \\
\left({ }^{\circ} \mathrm{C}\right)\end{array}$ & $\begin{array}{c}\text { Test } \\
\text { result } \\
\left({ }^{\circ} \mathrm{C}\right)\end{array}$ & $\begin{array}{c}\text { Error } \\
(\%)\end{array}$ & $\begin{array}{l}\text { Time } \\
\text { (hrs) }\end{array}$ & $\begin{array}{c}\text { Model } \\
\text { result } \\
\left({ }^{\circ} \mathrm{C}\right)\end{array}$ & $\begin{array}{c}\text { Test } \\
\text { result } \\
\left({ }^{\circ} \mathrm{C}\right)\end{array}$ & $\begin{array}{c}\text { Error } \\
(\%)\end{array}$ & $\begin{array}{l}\text { Time } \\
\text { (hrs) }\end{array}$ & $\begin{array}{l}\text { Model } \\
\text { result } \\
\left({ }^{\circ} \mathrm{C}\right)\end{array}$ & $\begin{array}{c}\text { Test } \\
\text { result } \\
\left({ }^{\circ} \mathrm{C}\right)\end{array}$ & $\begin{array}{c}\text { Error } \\
(\%)\end{array}$ & $\begin{array}{l}\text { Time } \\
\text { (hrs) }\end{array}$ & $\begin{array}{l}\text { Model } \\
\text { result } \\
\left({ }^{\circ} \mathrm{C}\right)\end{array}$ & $\begin{array}{c}\text { Test } \\
\text { result } \\
\left({ }^{\circ} \mathrm{C}\right)\end{array}$ & $\begin{array}{c}\text { Error } \\
(\%)\end{array}$ \\
\hline 0 & 13.45 & 12.88 & 4.2 & 0 & 13.45 & 12.78 & 5.0 & 0 & 13.40 & 12.51 & 6.6 & 0 & 13.42 & 12.62 & 6.0 \\
\hline 408 & 13.26 & 12.74 & 3.9 & 408 & 13.30 & 12.31 & 7.4 & 408 & 12.98 & 12.27 & 5.5 & 408 & 12.83 & 12.19 & 5.0 \\
\hline 1560 & 12.82 & 11.41 & 11.0 & 2400 & 11.86 & 10.85 & 8.5 & 1200 & 12.28 & 11.44 & 6.8 & 1560 & 10.46 & 11.36 & 8.6 \\
\hline 1920 & 12.31 & 11.08 & 10.0 & 2520 & 11.78 & 10.45 & 11.3 & 1320 & 12.26 & 11.38 & 7.2 & 1920 & 10.13 & 10.97 & 8.3 \\
\hline 3500 & 10.63 & 12.04 & 13.3 & 3000 & 10.62 & 11.4 & 7.3 & 3240 & 9.65 & 10.26 & 6.3 & 2640 & 9.33 & 10.32 & 10.6 \\
\hline 4176 & 10.00 & 10.45 & 4.5 & 3792 & 9.87 & 10.43 & 5.7 & 3600 & 9.41 & 9.96 & 5.8 & 4008 & 8.87 & 10.16 & 14.5 \\
\hline 4320 & 9.97 & 10.65 & 6.8 & 4320 & 9.75 & 10.61 & 8.8 & 3960 & 9.33 & 10.06 & 7.8 & 4440 & 8.92 & 9.21 & 3.3 \\
\hline 4500 & 9.98 & 10.46 & 4.8 & 4500 & 9.76 & 10.52 & 7.8 & 4500 & 9.42 & 10.32 & 9.6 & 4500 & 8.93 & 9.27 & 3.8 \\
\hline
\end{tabular}

\subsection{Outlet fluid temperatures}

The average outlet fluid temperatures are shown in Fig. 7 with the initial inlet fluid temperature of $1.2{ }^{\circ} \mathrm{C}$ and a flow rate of $0.38 \mathrm{~m}^{3} / \mathrm{h}$. The inlet fluid temperature is lower than the outlet fluid's, so the soil is a "heat source" in this operation mode. Fig. 7 demonstrates that the experimental and simulation results are in good agreement. As shown in Fig.7, the outlet fluid temperatures 
at the beginning of operation stage are different from the experimental results. This is because the input initial soil temperature is higher than the experimental data, which results in the high outlet fluid temperature from the simulation program. It is observed that the fluid temperature difference between inlet and outlet is around $6{ }^{\circ} \mathrm{C}$ at the initial stage while the temperature difference is only $4^{\circ} \mathrm{C}$ after 250 hours. The maximum fluid outlet temperature difference between the experimental and simulated results appears at the beginning, reaching $8.8 \%$. Thereby, the proposed model is able to be applied for short timescale response. Moreover, the mean error for the working fluid outlet temperature is $2.9 \%$. The difference could be caused by the simplified assumptions in numerical model.

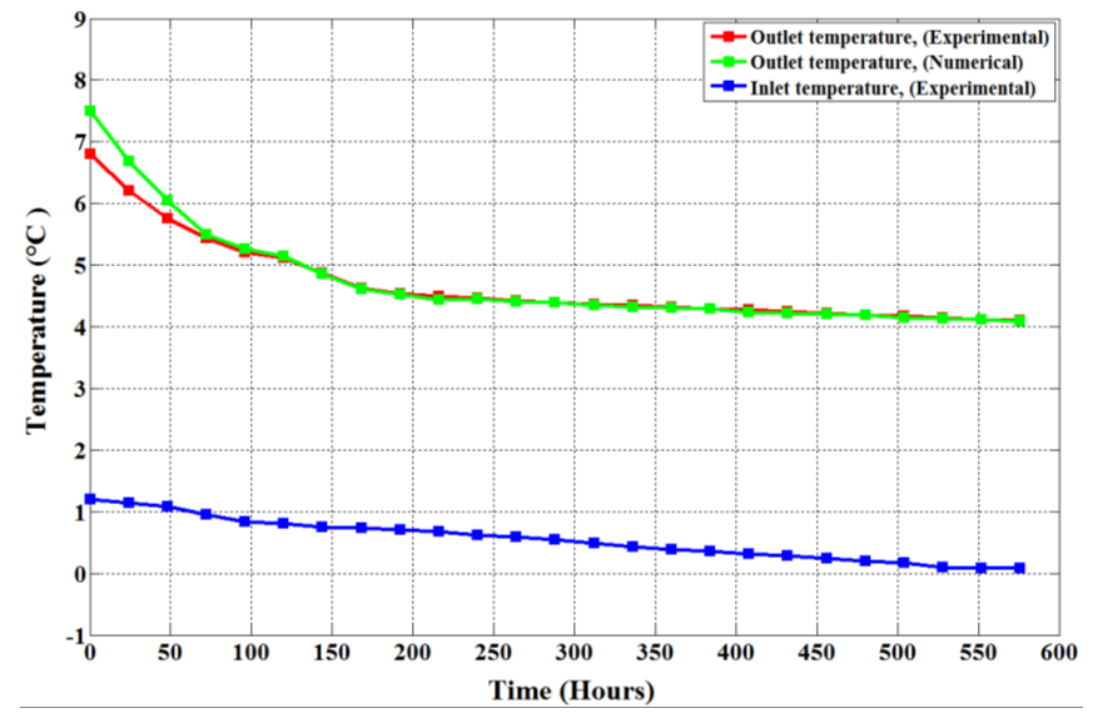

Fig.7. Fluid inlet and outlet temperatures

\subsection{Pile temperatures}

The pile temperatures at a depth of $10 \mathrm{~m}$ are shown in Fig. 8 decreasing from the beginning to the end of operation. At the end of operation, the highest pile temperature is obtained from pile 10 (referring to Fig. 6) while the lowest pile temperature is from pile 13. The pile temperatures obtained from the simulation indicate similar variation patterns as the experimental data over the whole operation period, the maximum errors are $13.3 \%, 11.3 \%, 9.6 \%$ and $14.5 \%$ for piles $10-13$, respectively, the maximum errors occurred around the middle of the operation time for piles 10, 11 and 13 while it happened at the end of the operation time for pile 12 . The mean errors for piles $10-13$ are $7.3 \%, 7.7 \%, 6.9 \%$ and $7.7 \%$ respectively. These data further verify the developed model. Notably, pile temperature variation may have influence on the foundation as a structural support because extra stress is generated within the pile due to temperature variation, so that the structural design of EP has to be taken into account. The ground thermal energy storage capacity between the piles increases with the pile spacing, which would enhance the pile heat extraction rate owing to more available heat source. Otherwise the pile heat transfer rate would decreases when the pile space is reduced. As for the EP depth influence on its heat exchange rate, it is possible to perform better heat exchange between the working fluid and surrounding soil. However, the initial cost is higher. 


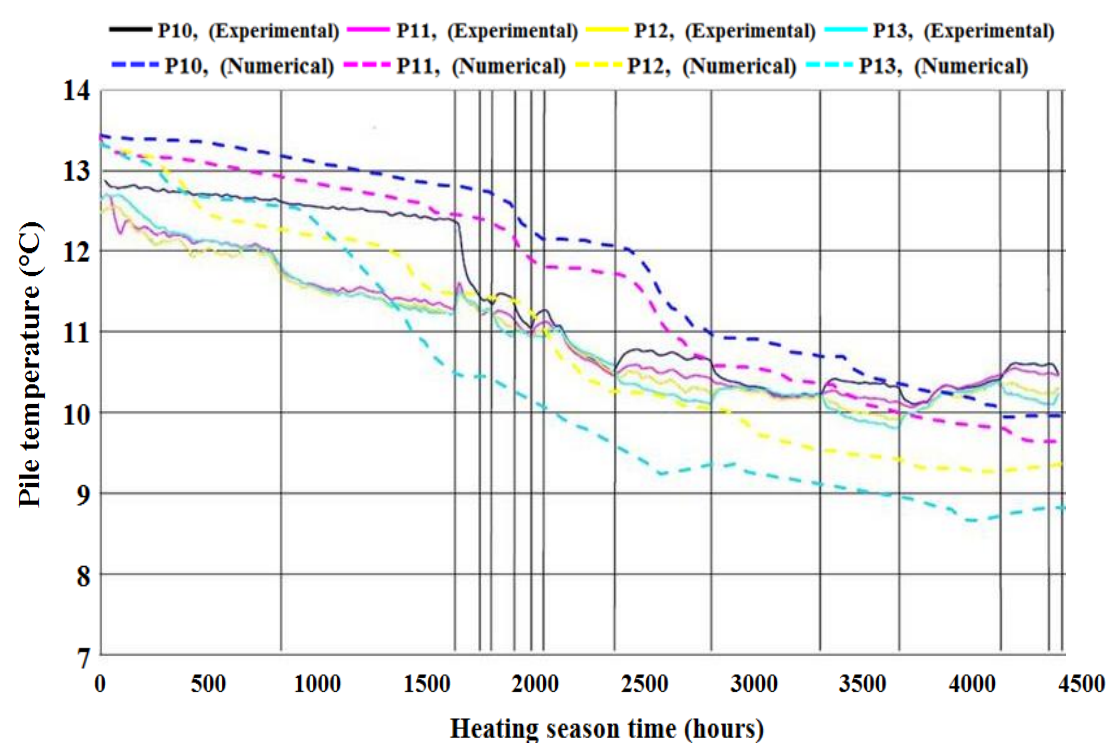

Fig.8. Pile temperatures

\subsection{Soil temperatures}

The soil is typically stratified along the pile with various materials including sand, clay, rock and so on. An array of thermocouples was located away from the piles 11 (such as at location C, D and E) at depths of $10 \mathrm{~m}$ to measure ground temperatures as shown in Fig. 6. The soil temperatures at the locations C, D and E are shown in Fig. 9 in which the simulation results show similar trends as the experimental data.

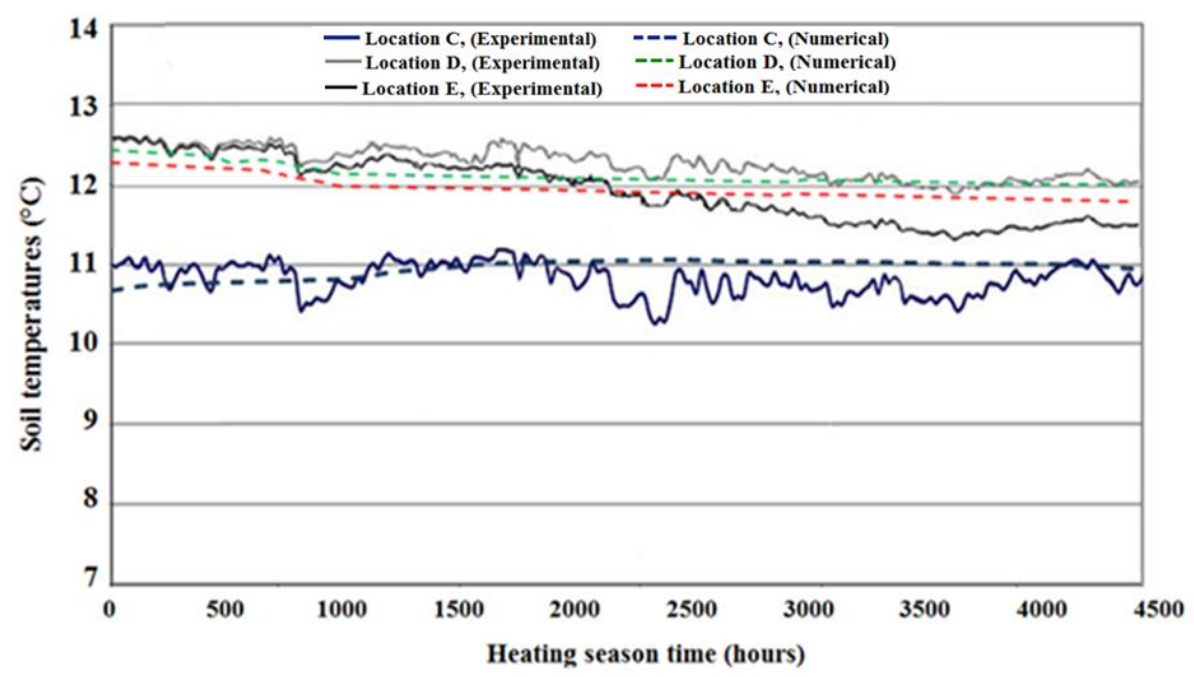

Fig.9. Soil temperatures at locations C, D and E

The soil at location $\mathrm{E}$ has greater temperature variation compared with that at location $\mathrm{D}$, meaning that it is more readily affected by heat extraction. The soil temperature variations at location $\mathrm{C}$, farthest from the plot and diagonally towards pile 11 , are lower compared with that at the locations D and E. This demonstrates that location C is thermally undisturbed by the energy pile plot or the effect is almost negligible. As indicated in Fig.9, the maximum soil temperature differences between the experimental and simulation results at the locations "C", " $\mathrm{D}$ " and "E" are 7.3\%,2.9\% and 5.1\% respectively, and these happened at the operation 
times of $2400 \mathrm{~h}, 1800 \mathrm{~h}$ and $3720 \mathrm{~h}$ correspondingly, the mean soil temperature errors at these locations are $3.6 \%, 1.1 \%$ and $3.2 \%$, respectively. These deviations could be due to the simplified assumptions in the mathematical model for example, the influence of groundwater flow is not considered in the 3D numerical model.

\subsection{Effects of fluid flow rate}

Fluid flow rate has a significant impact on the fluid outlet temperature and heat transfer rate of the EP system. The low flow rate could provide high temperature fluid for heat pump evaporator in the heating mode, but heat transfer rate is low due to low convective heat transfer between the fluid and U-tube. High flow rate could increase heat transfer rate but the fluid outlet temperature will remain low. In addition, high fluid flow rate also leads to more power consumption for the circulating pump. As a consequence, one issue in this study is to maintain the working fluid flow rate within a reasonable range. In order to address the impact of flow rate, the inlet fluid temperature is defined as $-4{ }^{\circ} \mathrm{C}$, this is because " $-4{ }^{\circ} \mathrm{C}$ " is regarded as the critical temperature of soil freezing. 30 days are used as the elapsed time in the simulation process. In addition, various flow rates, namely, $0.1 \mathrm{~m}^{3} / \mathrm{h}$, $0.3 \mathrm{~m}^{3} / \mathrm{h}, 0.5 \mathrm{~m}^{3} / \mathrm{h}, 0.7 \mathrm{~m}^{3} / \mathrm{h}, 0.9 \mathrm{~m}^{3} / \mathrm{h}$ and $1.2 \mathrm{~m}^{3} / \mathrm{h}$ are simulated, and correspondingly the outlet fluid temperatures and heat transfer rates are displayed in Fig. 10.

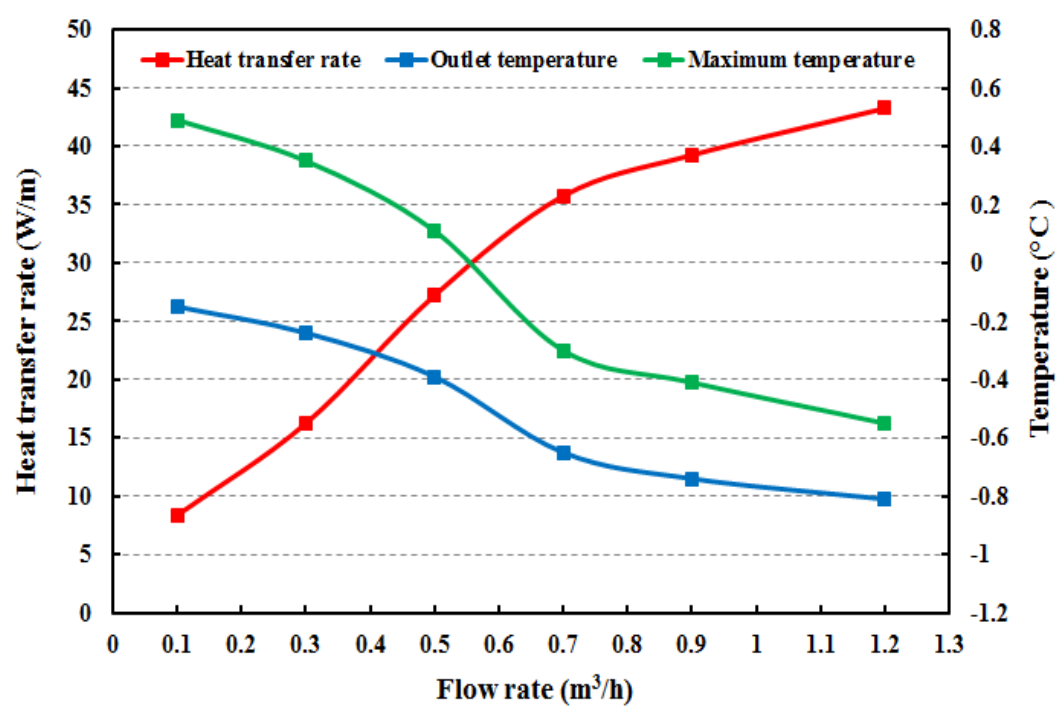

Fig.10. Influences of fluid flow rate

It is found that the flow rate has less effect on the heat transfer rate over a certain level. At low flow rate, convective heat transfer between the working fluid and pipe is the main thermal resistance in the EP. The convective coefficient can be enhanced by increasing flow rate. When flow rate is increased to a certain level, the convective heat transfer has less influence on the whole heat transfer process so that the overall heat transfer rate has a low increase trend with flow rate. The fluid temperature variations in the U-tube are shown in Fig. 11. Specifically, the outlet temperatures are $-0.15^{\circ} \mathrm{C}$ and $-0.81{ }^{\circ} \mathrm{C}$ for the flow rates of $0.1 \mathrm{~m}^{3} / \mathrm{h}$ and $1.2 \mathrm{~m}^{3} / \mathrm{h}$ with the corresponding fluid temperature increments of $3.85^{\circ} \mathrm{C}$ and $3.19^{\circ} \mathrm{C}$ respectively. It is found that the fluid 
outlet temperature is not the maximum one, which indicates there is heat loss in the U-tube even though under heat extraction mode. The loss is caused by heat exchange between two pipes of the U-tube, which is "thermal short-circuiting".

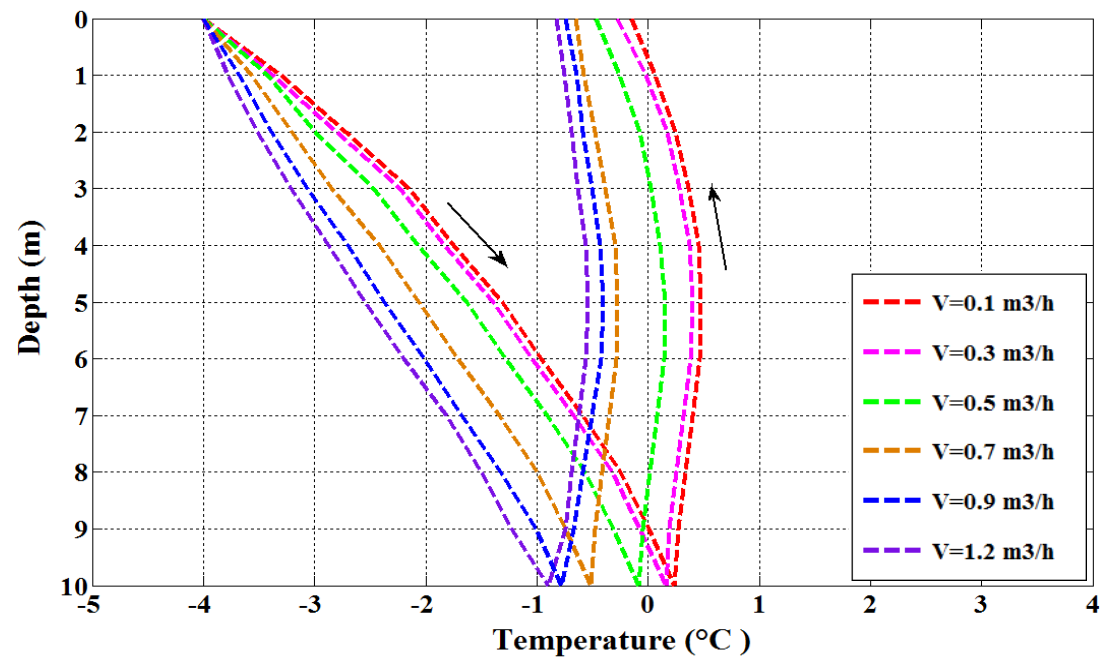

Fig.11. Fluid temperature distribution in the U-tube

As shown in Fig. 11, the fluid temperature within the inlet pipe always increases along the pipe whereas its temperature within the outlet pipe increases slowly at first, and then decreases due to the impact of "thermal short-circuiting". The highest fluid temperature occurs at the middle of the outlet pipe for example, it is $0.49{ }^{\circ} \mathrm{C}$ when the flow rate is $0.1 \mathrm{~m}^{3} / \mathrm{h}$. The maximum temperature difference between inlet and outlet is $4.49^{\circ} \mathrm{C}$ at the moment though the fluid outlet temperature is $-0.15{ }^{\circ} \mathrm{C}$ implying that the actual temperature difference between inlet and outlet is $3.85{ }^{\circ} \mathrm{C}$. Therefore the short-circuiting loss rate is $14.3 \%$ [(4.49$3.85) / 4.49=14.3 \%$ ]. Similarly, the short-circuiting effects at various flow rates are presented in Table 4 where it is indicated that the influence would be more serious at low flow rate due to the big temperature difference between inlet and outlet. Therefore, the effect of "thermal short-circuiting" should be given full consideration in practical application.

Table 4 Thermal short-circuiting loss

\begin{tabular}{|l|c|c|c|c|c|c|}
\hline Flow rate $\left(\mathbf{m}^{\mathbf{3}} / \mathbf{h}\right)$ & $\mathbf{0 . 1}$ & $\mathbf{0 . 3}$ & $\mathbf{0 . 5}$ & $\mathbf{0 . 7}$ & $\mathbf{0 . 9}$ & $\mathbf{1 . 2}$ \\
\hline Inlet temperature $\left({ }^{\circ} \mathbf{C}\right)$ & -4 & -4 & -4 & -4 & -4 & -4 \\
\hline Outlet temperature $\left({ }^{\circ} \mathbf{C}\right)$ & -0.15 & -0.24 & -0.39 & -0.65 & -0.74 & -0.81 \\
\hline $\begin{array}{l}\text { Maximum temperature } \\
\left({ }^{\circ} \mathbf{C}\right)\end{array}$ & 0.49 & 0.35 & 0.11 & -0.30 & -0.41 & -0.55 \\
\hline $\begin{array}{l}\text { Temperature difference } \\
\text { between inlet and outlet } \\
\left({ }^{\circ} \mathbf{C}\right)\end{array}$ & 3.85 & 3.76 & 3.61 & 3.34 & 3.26 & 3.19 \\
\hline $\begin{array}{l}\text { Maximum temperature } \\
\text { difference }\left({ }^{\circ} \mathbf{C}\right)\end{array}$ & 4.49 & 4.35 & 4.12 & 3.70 & 3.59 & 3.45 \\
\hline $\begin{array}{l}\text { Short circuiting loss rate } \\
(\%)\end{array}$ & 14.3 & 13.5 & 12.3 & 9.6 & 9.2 & 7.5 \\
\hline
\end{tabular}

To sum up, low flow rate is able to provide high temperature fluid to increase EP efficiency by enhancing the evaporative temperature, but in the meantime it has low heat transfer rate and high "thermal short-circuiting" loss. As for high flow rate, it has high heat transfer rate and low short-circuiting heat loss, but it provides low temperature fluid for heat pump. Therefore, in 
this study, the fluid flow rate should be controlled in the range of $0.5 \mathrm{~m}^{3} / \mathrm{h}$ to $0.7 \mathrm{~m}^{3} / \mathrm{h}$. The influence of the working fluid flow rate is also investigated in the literature [45], the fluid flow velocity within a U-tube pipe with internal diameter of $0.026 \mathrm{~m}$ should be in the range from $0.3 \mathrm{~m} / \mathrm{s}$ to $0.4 \mathrm{~m} / \mathrm{s}$, correspondingly the flow rate range is $0.57 \mathrm{~m}^{3} / \mathrm{h}$ to $0.76 \mathrm{~m}^{3} / \mathrm{h}$, which is nearly consistent with the above suggested flow rate range.

\subsection{Effects of U-tube shank spacing}

The inlet and outlet pipes are so close that unavoidably causes "thermal short-circuiting". Hence, it is essential to address the effect of shank spacing on thermal behaviour of the EP. The working fluid temperatures at different shank spacing, namely 0m, $0.02 \mathrm{~m}, 0.04 \mathrm{~m}, 0.06 \mathrm{~m}, 0.08 \mathrm{~m}$ and $0.10 \mathrm{~m}$, are shown in Fig. 12 with a flow rate of $0.5 \mathrm{~m}^{3} / \mathrm{h}$. It is found that the outlet fluid temperature increases with shank spacing. The fluid temperature within the outlet pipe increases at first when the two pipes are very close to each other, and then decreases due to the heat loss caused by "thermal short-circuiting". The effect of "thermal short-circuiting" is most serious when the two pipes are in contact with each other and its influence decreases with shank spacing.

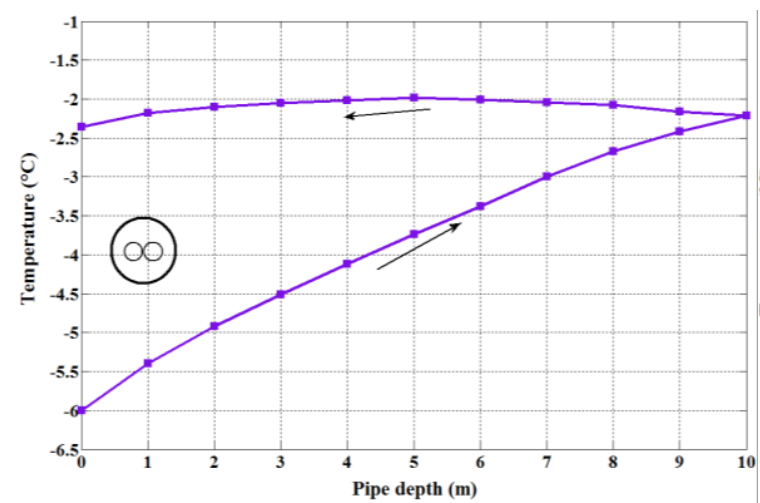

(a) Shank spacing: zero

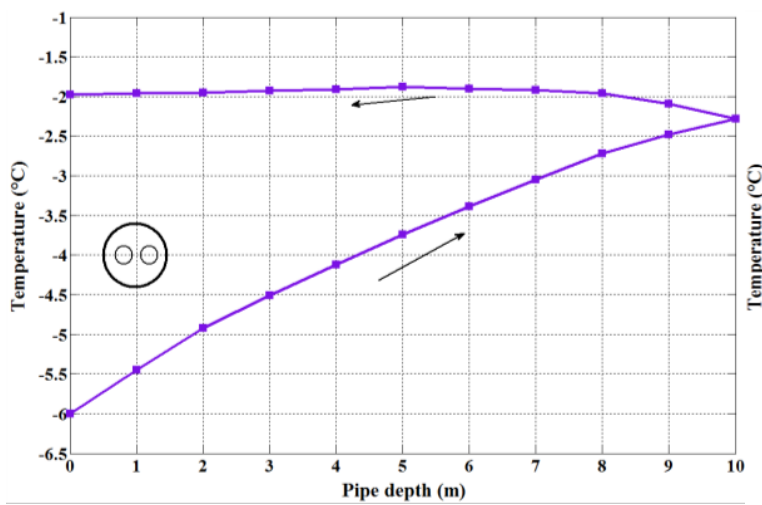

(c) Shank spacing: $0.04 \mathrm{~m}$

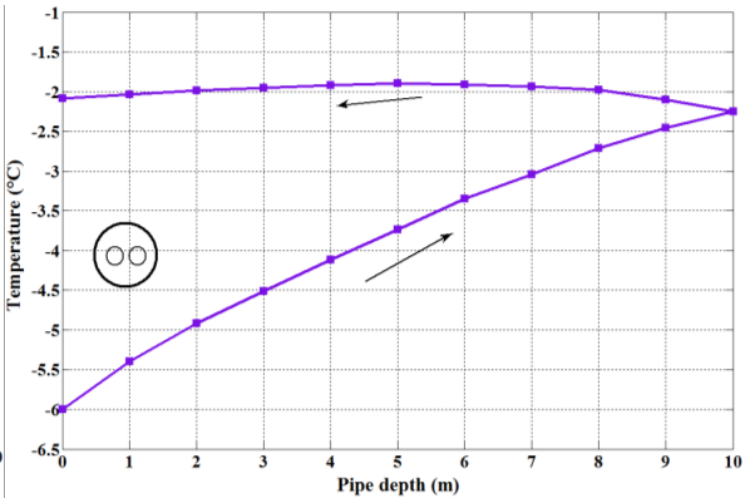

(b) Shank spacing: $0.02 \mathrm{~m}$

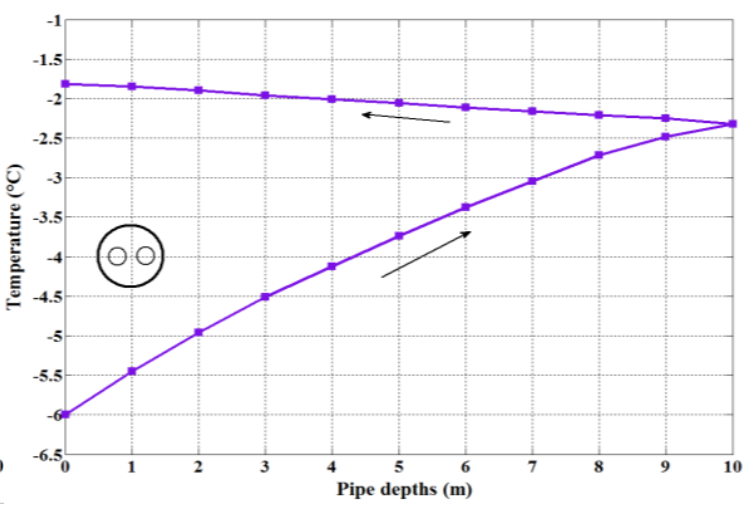

(d) Shank spacing: $0.06 \mathrm{~m}$ 


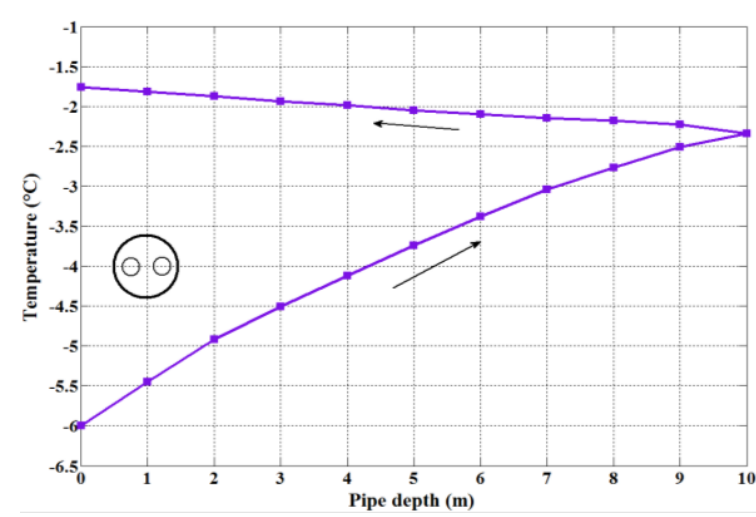

(e) Shank spacing: $0.08 \mathrm{~m}$

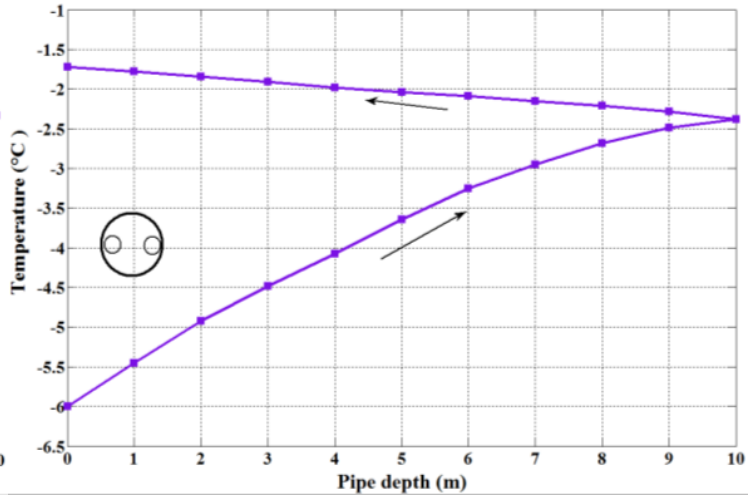

(f) Shank spacing: $0.10 \mathrm{~m}$

Fig.12. Outlet fluid temperature variation with shank spacing

The influence of shank spacing on heat transfer rate is shown in Fig.13. It can be seen that heat transfer rate increases gradually with shank spacing while its increasing rate decreases progressively. The shank spacing has less influence when it is larger than $0.06 \mathrm{~m}$. This is because thermal resistance between inlet and outlet pipes increases gradually with shank spacing. Therefore heat exchange between two pipes decreases so that the influence caused by "thermal short-circuiting" becomes less accordingly. Hence, it is possible to reduce the influence of "thermal short-circuiting" by means of increasing the distance between two pipes of U-tube. However the shank spacing is limited by the EP dimension, the maximum value of which is $0.1 \mathrm{~m}$ in this study. $0.072 \mathrm{~m}$ shank spacing is adopted in the literature [46] to analyse heat transfer efficiency in an EP foundation, where a U-tube pipe with internal diameter of $0.02 \mathrm{~m}$ and external diameter of $0.028 \mathrm{~m}$ is installed. $0.098 \mathrm{~m}$ shank spacing is used in the literature [47] to test the EP thermal response, the EP diameter is $0.3 \mathrm{~m}$ with a $0.032 \mathrm{~m}$ diameter pipe installed. These data approve the above shank spacing analysis results.

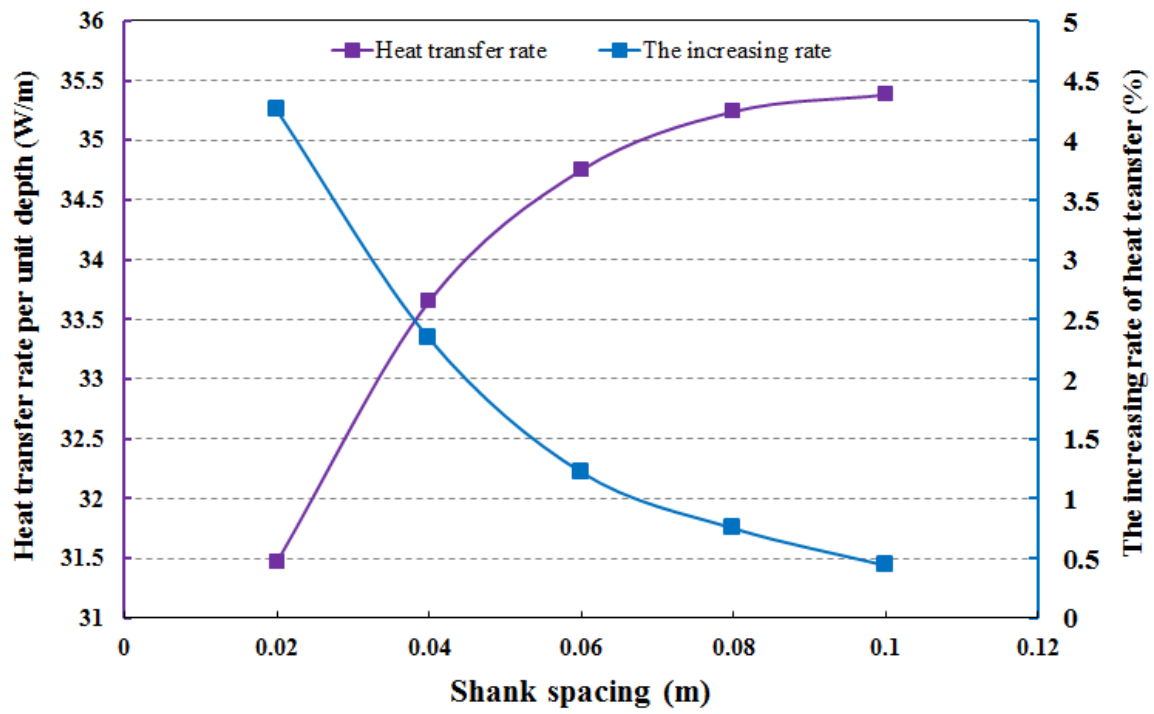

Fig.13. Influences of shank spacing on heat transfer rate 


\section{Conclusions}

A three-dimensional transient heat transfer model is developed to investigate thermal properties of multiple energy piles, which is based on the finite volume method. The normal circular cross-section EP region is replaced by an equivalent rectangular geometry with full interpretation of heat transfer process within the EP system. Energy balance models in solid and fluid regions are set up separately; EP boundary conditions are established for various conjugated surfaces. The numerical model is compiled and validated by experimental data in respect of outlet fluid, pile and soil temperatures. The influences of "thermal shortcircuiting" between the two pipes of U-tube in the EP on the outlet fluid temperature and heat transfer rate are investigated, the effects of the working fluid flow rate are examined as well. In order to avoid low outlet fluid temperature and reduce the effect of "thermal short-circuiting", the fluid flow rate should be controlled in the range of $0.5 \mathrm{~m}^{3} / \mathrm{h}$ to $0.7 \mathrm{~m}^{3} / \mathrm{h}$ in this study. Heat transfer between two pipes of U-tube is analysed with different U-tube shank spacing, and it is found that heat transfer rate per unit depth increases gradually with the distance between two pipes but the increasing rate of heat transfer reduces progressively. To reduce the impact of "thermal short-circuiting", the shank spacing should be set in a range of $0.06 \mathrm{~m}$ to $0.10 \mathrm{~m}$ in this study. Even though small errors involved in the fluid outlet, pile and soil temperatures exist, it can be concluded that the numerical approach is capable of coupling the soil temperature to the working fluid temperature. The developed 3D mathematical model is validated by the experimental data, and the model can be used to explore the EP performance further. Therefore, a case study of GSHP system using energy piles is the future research work to assess the system energy performance for whole year period.

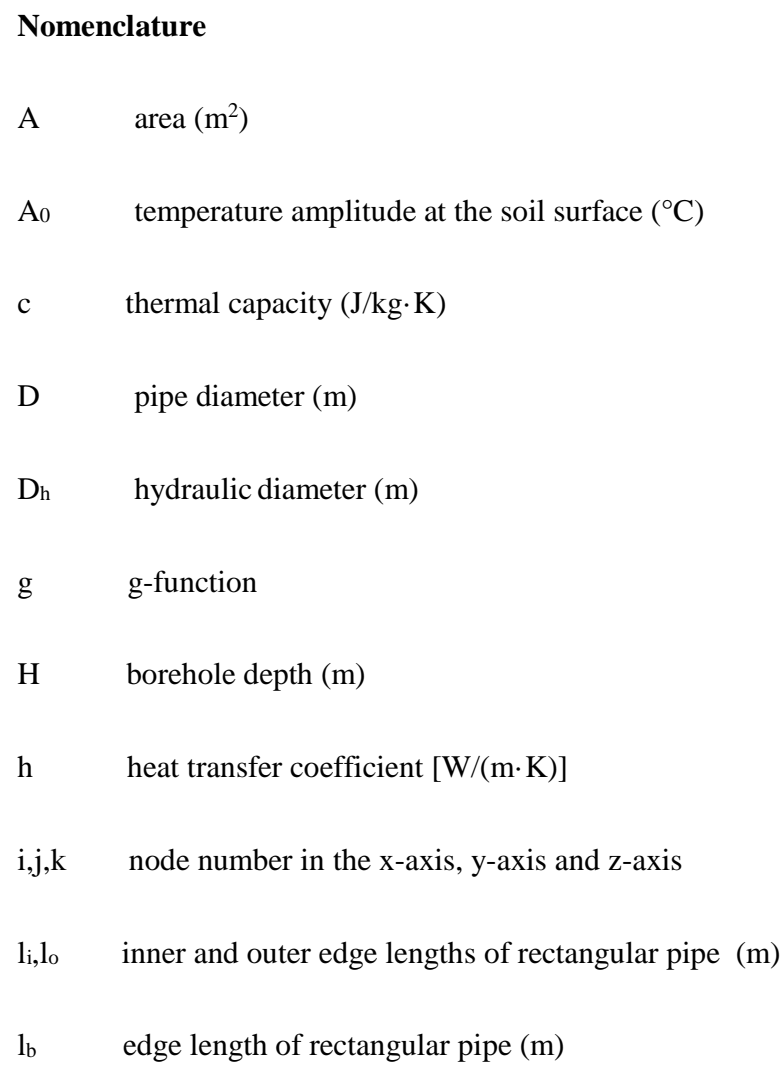




\begin{tabular}{|c|c|}
\hline \multicolumn{2}{|r|}{ thermal conductivity $[\mathrm{W} /(\mathrm{m} \cdot \mathrm{K})]$} \\
\hline \multicolumn{2}{|r|}{ radius $(\mathrm{m})$} \\
\hline $\mathrm{R}$ & thermal resistance $(\mathrm{m} \cdot \mathrm{K} / \mathrm{W})$ \\
\hline $\mathrm{T}$ & temperature $\left({ }^{\circ} \mathrm{C}\right)$ \\
\hline $\mathrm{T}_{0}$ & ground far field temperature $\left({ }^{\circ} \mathrm{C}\right)$ \\
\hline $\mathrm{t}$ & time $(\mathrm{s})$ \\
\hline \multicolumn{2}{|c|}{ Subscripts } \\
\hline \multicolumn{2}{|c|}{ ave average } \\
\hline $\mathrm{b}$ & borehole \\
\hline cond & conduction \\
\hline conv & convection \\
\hline $\mathrm{f}$ & fluid \\
\hline grout & grout \\
\hline $\mathrm{i}$ & inside \\
\hline o & outside \\
\hline $\mathrm{s}$ & soil \\
\hline $\mathrm{w}$ & wall \\
\hline \multicolumn{2}{|c|}{$\mathrm{w}, \mathrm{e}, \mathrm{s}, \mathrm{n}, \mathrm{b}, \mathrm{t}$ west, east, south, north, bottom, top } \\
\hline \multicolumn{2}{|c|}{ Greek Letters } \\
\hline$\alpha$ & ground thermal conductivity $(\mathrm{J} / \mathrm{kg} \cdot \mathrm{K})$ \\
\hline$\Delta \mathrm{d}$ & distance between centre to centre (m) \\
\hline$\Delta \mathrm{t}$ & iterative time (s) \\
\hline \multicolumn{2}{|c|}{$\Delta \mathrm{x}, \Delta \mathrm{y}, \Delta \mathrm{z}$ space interval at different direction } \\
\hline$\rho$ & density $\left(\mathrm{kg} / \mathrm{m}^{3}\right)$ \\
\hline$\mu, \mu$ & fluid velocities in the U-tube and square pipes $(\mathrm{m} / \mathrm{s})$ \\
\hline Abbr & viations \\
\hline
\end{tabular}




\begin{tabular}{|ll|}
\hline BHE & borehole heat exchanger \\
FDM & fapacity resistance model \\
FEM & finite element method \\
FVM & finite volume method \\
GSHP & ground source heat pump \\
TRCM & thermal resistance capacity model \\
1D & one-dimensional \\
2D & two-dimensional \\
3D & three-dimensional \\
\hline
\end{tabular}

\section{Acknowledgement}

The authors would like to thank Mr Jianxun Dang for his help with computer technology

\section{References}

[1] C. J. Wood, Investigation of Novel Ground source Heat Pump, in: Built Environment, Vol. Doctor of Philosophy, University of Nottingham, 2009.

[2] E. H. N. Gashti, M. Malaska, K. Kujala, Evaluation of thermo-mechanical behaviour of composite energy piles during heating/cooling operations, Engineering Structures, 75 (2014) 363-373.

[3] Y. Hamada, H. Saitoh, M. Nakamura, H. Kubota, K. Ochifuji, Field performance of an energy pile system for space heating, Energy and Buildings, 39 (2007) 517-524.

[4] J. Gao, X. Zhang, J. Liu, K.S. Li, J. Yang, Thermal performance and ground temperature of vertical pile-foundation heat exchangers: A case study, Applied Thermal Engineering, 28 (2008) 2295-2304.

[5] J. Gao, X. Zhang, J. Liu, K. Li, J. Yang, Numerical and experimental assessment of thermal performance of vertical energy piles: An application, Applied Energy, 85 (2008) 901-910.

[6] H. Brandl, Energy foundations and other thermo-active ground structures, Geotechnique, (2006) 56, No.2, 81-122.

[7] P. Cui, X. Li, Y. Man, Z. Fang, Heat transfer analysis of pile geothermal heat exchangers with spiral coils, Applied Energy, 88 (2011) 4113-4119. 
[8] M. de Moel, P.M. Bach, A. Bouazza, R.M. Singh, J.O. Sun, Technological advances and applications of geothermal energy pile foundations and their feasibility in Australia, Renewable and Sustainable Energy Reviews, 14 (2010) 2683-2696.

[9] M.E. Suryatriyastuti, H. Mroueh, S. Burlon, Understanding the temperature-induced mechanical behaviour of energy pile foundations, Renewable and Sustainable Energy Reviews, 16 (2012) 3344-3354.

[10] P. Eskilson, Thermal Analysis of Heat Extraction Boreholes, University of Lund, Sweden, 1987.

[11] G. Hellstrom, 1989. Duct ground heat storage model: Manual for computer code. Lund, Sweden: University of Lund, Department of Mathematical physics.

[12] G. Hellstrom, 1991. Ground heat storage. Thermal analysis of duct storage systems: Part I Theory. Lund, Sweden: University of Lund, Department of Mathematical Physics.

[13] C. Yavuzturk, J. D. Spitler, A Short Time Step Response Factor Model for Vertical Ground Loop Heat Exchangers, ASHRAE Transactions, 1999.

[14] C. Yavuzturk, J. D. Spitler, S. J. Rees, A Transient Two-Dimensional Finite Volume Model for the Simulation of Vertical U-Tube Ground Heat Exchangers, Ashrae Transactions 1996, Vol 102, Pt 1, (1999) 105, 465-474.

[15] C. Yavuzturk, A.D. Chiasson, J.E. Nydahl, Simulation Model for Ground Loop Heat Exchangers, in: Ashrae Transactions 2009, Vol 115, Pt 2, Vol. 115, 2009, pp. 45-59.

[16] I. R. Maestre, F. J. G. Gallero, P. A. Gomez, J. D. M. Balades, Performance assessment of a simplified hybrid model for a vertical ground heat exchanger, Energy and Buildings, 66(2013) 437-444.

[17] A. Huber, M. Wetter., Vertical borehole heat exchanger EWS model, (1997).

[18] T. Oppelt, I. Riehl, U. Gross, Modelling of the borehole filling of double U-pipe heat exchangers, Geothermics, 39 (2010) $270-276$.

[19] M. De Carli, M. Tonon, A. Zarrella, R. Zecchin, A computational capacity resistance model (CaRM) for vertical groundcoupled heat exchangers, Renewable Energy, 35 (2010) 1537-1550.

[20] A. Zarrella, M. Scarpa, M. De Carli, Short time step analysis of vertical ground-coupled heat exchangers: The approach of CaRM, Renewable Energy, 36 (2011) 2357-2367.

[21] D. Bozis, K. Papakostas, N. Kyriakis. On the evaluation of design parameters effects on the heat transfer efficiency of energy piles, Energy and Buildings, 43(2011) 1020-1029.

[22] P. Hu, J. Zha, F. Lei, N. Zhu, T. Wu, Composite cylindrical model and its application in analysis of thermal response and performance for energy pile, Energy and Buildings, 84 (2014) 324-332.

[23] D. Bauer, W. Heidemann, H. Muller-Steinhagen, H.-J.G. Diersch, Thermal resistance and capacity models for borehole heat exchangers, International Journal Of Energy Research, 35 (2011) 312-320. 
[24] A. Huber and O. Schuler, Berechnungsmodul für Erdwärmesonden“, Swiss Federal Office of Energy, Bern Switzerland, 1997.

[25] P. Pasquier, D. Marcotte, Short-term simulation of ground heat exchanger with an improved TRCM, Renewable Energy, 46 (2012) 92-99.

[26] R. A. Beier, J. Acuña, P. Mogensen, B. Palm, Borehole resistance and vertical temperature profiles in coaxial borehole heat exchangers, Applied Energy, 102 (2013) 665-675.

[27] C. J. Wood, H. Liu, S.B. Riffat, An investigation of the heat pump performance and ground temperature of a piled foundation heat exchanger system for a residential building, Energy, 35 (2010) 4932-4940.

[28] R. Al-Khoury, P.G. Bonnier, R.B J.Brinkgreve, Efficient finite element formulation for geothermal heating systems. Part I: Steady state, International Journal for Numerical Methods In Engineering, 63 (2005) 988-1013.

[29] R. Al-Khoury, T. Kölbel, R. Schramedei, Efficient numerical modeling of borehole heat exchangers, Computers \& Geosciences, 36 (2010) 1301-1315.

[30] R. Al-Khoury, P.G. Bonnier, Efficient finite element formulation for geothermal heating systems. Part II: Transient, International Journal for Numerical Methods In Engineering, 67 (2006) 725-745.

[31] M. Nabi, R. Al-Khoury, An efficient finite volume model for shallow geothermal systems. Part I: Model formulation, Computers \& Geosciences, 49 (2012) 290-296.

[32] M. Nabi, R. Al-Khoury, An efficient finite volume model for shallow geothermal systems-Part II: Verification, validation and grid convergence, Computers \& Geosciences, 49 (2012) 297-307.

[33] S.J. Rees, M. He, A three-dimensional numerical model of borehole heat exchanger heat transfer and fluid flow, Geothermics, 46 (2013) 1-13.

[34] M. He, Numerical Modelling of Geothermal Borehole Heat Exchanger Systems, in: Institute of Energy and Sustainable Development, Vol. PhD, De Montfort University, Leicester, UK, 2012.

[35] E. H. N. Gashti, V.-M. Uotinen, K. Kujala. Numerical modelling of thermal regimes in steel energy pile foundations: A case study, Energy and Buildings, 69 (2014) 165-174.

[36] N. BniLam, R. Al-Khoury, A Spectral Model for Heat Transfer with Friction Heat Gain in Geothermal Borehole Heat Exchangers, Applied Mathematical Modelling (2016) 1-12.

[37] C. K. Lee. A modified three-dimensional numerical model for predicting the short-time-step performance of borehole ground heat exchangers, Renewable Energy 87 (2016) 618-627.

[38] S. E. Dehkordi, R. A. Schincariol, S. Reitsma, Thermal performance of a tight borehole heat exchanger, Renewable Energy $83(2015)$ 698-704. 
[39] M. Yu, T. Ma, K. Zhang, P. Cui, A. Hu, Z. Fang, Simplified heat transfer analysis method for large-scale boreholes ground heat exchangers, Energy and Buildings 116 (2016) 593-601.

[40] Choi and Ooka, Effect of disturbance on thermal response test, part 1: Development of disturbance analytical model, parametric study, and sensitivity analysis, Renewable Energy 85 (2016) 306-318.

[41] Choi and Ooka, Effect of disturbance on thermal response test, part 2: Numerical study of applicability and limitation of infinite line source model for interpretation under disturbance from outdoor environment, Renewable Energy 85 (2016) 1090-1105.

[42] D. L. Nofziger, Soil Temperature Variations with Time and Depth, 2003.

[43] G. A. Florides, S. A. Kalogirou, Annual ground temperature measurements at various depths, 2004.

[44] T. Kusuda, O.Plet, J.W. Bean, Annual Variation of Temperature Field and Heat Transfer under Heated Ground Surfaces: Slab-on-Grade Floor Heat Loss Calculations.

[45] B. Bouhacina, R. Saim, H. Benzenine, H. F. Oztopc, Analysis of thermal and dynamic comportment of a geothermal vertical U-tube heat exchanger, Energy and Buildings 58 (2013) 37-43.

[46] A. A. Mehrizi, S. Porkhial, B. Bezyan, H. Lotfizadeh, Energy pile foundation simulation for different configurations of ground source heat exchanger, International Communications in Heat and Mass Transfer 70 (2016) 105-114.

[47] F. Cecinato, F. A. Loveridge, Influences on the thermal efficiency of energy piles, Energy 82 (2015) $1021-1033$. 